\section{OPEN ACCESS}

Edited by:

Marcelino T. Suzuki,

Sorbonne Universités, France

Reviewed by:

Calvin A. Henard,

National Renewable Energy Laboratory (DOE), United States Jenan Kharbush,

Harvard University, United States

${ }^{*}$ Correspondence:

Nicole J. Bale

nicole.bale@nioz.n

Specialty section:

This article was submitted to

Aquatic Microbiology,

a section of the journal

Frontiers in Microbiology

Received: 12 October 2018

Accepted: 07 March 2019

Published: 05 April 2019

Citation:

Bale NJ, Rijpstra WIC Sahonero-Canavesi DX, Oshkin IY,

Belova SE, Dedysh SN and

Sinninghe Damsté JS (2019) Fatty

Acid and Hopanoid Adaption to Cold in the Methanotroph Methylovulum

psychrotolerans.

Front. Microbiol. 10:589.

doi: 10.3389/fmicb.2019.00589

\title{
Fatty Acid and Hopanoid Adaption to Cold in the Methanotroph Methylovulum psychrotolerans
}

Nicole J. Bale1*, W. Irene C. Rijpstra ${ }^{1}$, Diana X. Sahonero-Canavesi', Igor Y. Oshkin ${ }^{2}$, Svetlana E. Belova ${ }^{2}$, Svetlana N. Dedysh ${ }^{2}$ and Jaap S. Sinninghe Damsté1,3
${ }^{1}$ Department of Marine Microbiology and Biogeochemistry, NIOZ Royal Institute for Sea Research, and Utrecht University, Texel, Netherlands, ${ }^{2}$ Research Center of Biotechnology of the Russian Academy of Sciences, Winogradsky Institute of Microbiology, Moscow, Russia, ${ }^{3}$ Department of Earth Sciences, Faculty of Geosciences, Utrecht University, Utrecht, Netherlands

Three strains of aerobic psychrotolerant methanotrophic bacteria Methylovulum psychrotolerans, isolated from geographically remote low-temperature environments in Northern Russia, were grown at three different growth temperatures, 20, 10 and $4^{\circ} \mathrm{C}$ and were found to be capable of oxidizing methane at all temperatures. The three M. psychrotolerans strains adapted their membranes to decreasing growth temperature by increasing the percent of unsaturated fatty acid (FAs), both for the bulk and intact polar lipid (IPL)-bound FAs. Furthermore, the ratio of $\beta O H-C_{16: 0}$ to $n-C_{16: 0}$ increased as growth temperature decreased. The IPL head group composition did not change as an adaption to temperature. The most notable hopanoid temperature adaptation of $M$. psychrotolerans was an increase in unsaturated hopanols with decreasing temperature. As the growth temperature decreased from 20 to $4^{\circ} \mathrm{C}$, the percent of unsaturated M. psychrotolerans bulk-FAs increased from 79 to $89 \%$ while the total percent of unsaturated hopanoids increased from 27 to $49 \%$. While increased FA unsaturation in response to decreased temperature is a commonly observed response in order to maintain the liquid-crystalline character of bacterial membranes, hopanoid unsaturation upon cold exposition has not previously been described. In order to investigate the mechanisms of both FA and hopanoid cold-adaption in M. psychrotolerans we identified genes in the genome of $M$. psychrotolerans that potentially code for FA and hopanoid desaturases. The unsaturation of hopanoids represents a novel membrane adaption to maintain homeostasis upon cold adaptation.

Keywords: methanotroph, bacteria, methane, temperature, fatty acid, hopanol

\section{INTRODUCTION}

Methylovulum psychrotolerans is a recently described species of aerobic methanotrophic bacteria, isolated from several low-temperature habitats in Northern Russia, such as cold methane seeps and subarctic freshwater lake sediments (Oshkin et al., 2016). These psychrotolerant methanotrophs are able to grow at temperatures between $2^{\circ} \mathrm{C}$ and $36^{\circ} \mathrm{C}$ and, although their optimum temperature range is $20-25^{\circ} \mathrm{C}$, they also grow well at lower temperatures, down to $4^{\circ} \mathrm{C}$. Members of the genus Methylovulum are characterized as Type I methanotrophs, as they belong to the 
Gammaproteobacteria and assimilate $\mathrm{C} 1$ compounds via the ribulose monophosphate pathway (RuMP) (Hanson and Hanson, 1996; Trotsenko and Murrell, 2008). The lipid characteristics of Type I methanotrophs include high levels of $n-\mathrm{C}_{16}$ fatty acids ( $\mathrm{C}_{16}$ FAs), and in particular, unsaturated $n-\mathrm{C}_{16}$ FAs (Hanson and Hanson, 1996; Nichols et al., 1985). However, species from the genera Methylovulum have been reported to also contain high levels of saturated $n-\mathrm{C}_{16}$ FA and $n-\mathrm{C}_{14}$ FA (Iguchi et al., 2011; Oshkin et al., 2016). $\beta$-hydroxy FAs have been detected in a range of methanotrophic bacteria (Bowman et al., 1991) and their source has been identified as the lipid A component of lipopolysaccharides (Wollenweber and Rietschel, 1990), which are a major constituent of the outer membrane of Gram-negative bacteria (Keinänen et al., 2003; Wollenweber and Rietschel, 1990). Methanotrophs also produce bacteriohopanepolyols (BHPs) which can be tetra, penta or hexafunctionalised (Cvejic et al., 2000a; van Winden et al., 2012b; Rush et al., 2016; Osborne et al., 2017). BHPs have been identified with a range of modifications including $3 \beta$-methylation and unsaturations at the $\Delta^{6}$ and $\Delta^{11}$ positions (Talbot et al., 2007a). BHPs (and hopanoid alcohols derived thereof) with an unsaturation at the $\Delta^{11}$ position have been observed in a Methylovulum-like strain M200 (van Winden et al., 2012b), and have been observed in combination with a $3 \beta$ methylation in the thermophilic Methylocaldum szegediense (Cvejic et al., 2000a) and in a range of acetic acid bacteria (Rohmer and Ourisson, 1976; Simonin et al., 1994; Herrmann et al., 1996).

The effect of temperature on bacterial membrane lipids has been extensively studied (Suutari and Laakso, 1994; Chintalapati et al., 2004; Barria et al., 2013). Indeed, in order to maintain sufficient membrane fluidity at low temperatures, bacteria adapt their membranes to lower the phase-transition temperature below which their membrane changes from a "fluid" (liquid-crystalline) to a "rigid" phase (Chattopadhyay, 2006; Guschina and Harwood, 2006; Shivaji and Prakash, 2010; Siliakus et al., 2017). These membrane adaptations to cold include increases in unsaturated FAs, short chain FAs and branched chain FAs as well as the incorporation of carotenoids and glycolipids. Several studies have described the membrane lipid composition and adaptation to cold in psychrophilic bacteria (which have an optimum growth temperature of $<15^{\circ} \mathrm{C}$ ) including Clostridium psychrophilum, Colwellia psychrerythraea and Psychromonas ingrahamii (Breezee et al., 2004; Auman et al., 2006; Guan et al., 2013; Wan et al., 2016). Membrane adaptation to cold in psychrotolerant bacteria (which have an optimum temperature between 20 and $40^{\circ} \mathrm{C}$, but are also capable of growth around $0^{\circ} \mathrm{C}$ ) has been studied for species including Sphingobacterium antarcticus and Micrococcus roseus (Chattopadhyay et al., 1997; Jagannadham et al., 2000). A range of species-specific adaptions were described for these psychrotolerant microorganisms including increases in unsaturated FAs, both increases and decreases in branched chain FAs and incorporation of polar and non-polar carotenoids into the membrane.

Changes in hopanoids with changing growth temperature has been reported for non-methanotrophs, such as Frateuria aurantia (Joyeux et al., 2004), Zymomonas mobilis (Hermans et al., 1991) and Bacillus acidocaldarius (Poralla et al., 1984). However, only a limited number of studies have examined the effect of temperature on the lipid composition of methanotrophic bacteria: a study of "CEL 1923" [thought to be Methylomonas methanica; Jahnke et al. (1999)], a mesocosm experiment with Sphagnum moss colonized by symbiotic methanotrophs (van Winden, 2011; van Winden et al., 2012a) and a study of methane-amended aerobic river-sediment incubations (Osborne et al., 2017).

In this study, three strains of $M$. psychrotolerans $\left(\mathrm{Sph} 1^{\mathrm{T}}\right.$, OZ2, and Sph56) were grown at three different growth temperatures, 20,10 and $4^{\circ} \mathrm{C}$. In order to examine growth temperature-driven changes in their lipid distribution, the FA distribution (bulk and IPL-bound) was examined at each growth temperature. The changes in hopanoids were examined by analysis of the hopanols formed by Rohmer degradation of intact BHPs.

\section{MATERIALS AND METHODS}

\section{Strains and Culture Conditions}

Three strains of Methylovulum psychrotolerans isolated from different geographical locations in Northern Russia were used in this study. The type strain of this species, $\mathrm{Sph} 1^{\mathrm{T}}$, was obtained from a cold methane seep located in the valley of the river Mukhrinskaya, Irtysh basin, West Siberia $\left(60^{\circ} 53.358^{\prime}\right.$ $\left.\mathrm{N} 68^{\circ} 42.486^{\prime} \mathrm{E}\right)$. Strain OZ2 was isolated from sediments of a subarctic, shallow, unnamed freshwater lake in Archangelsk region ( $\left.67^{\circ} 36.567^{\prime} \mathrm{N} 53^{\circ} 35.317^{\prime} \mathrm{E}\right)$. These two strains were characterized in detail by Oshkin et al. (2016). The third strain, designated Sph56, was isolated from sediments of an arctic, unnamed freshwater lake located on the island Belyy in the Kara Sea $\left(73^{\circ} 20.25^{\prime} \mathrm{N} 70^{\circ} 10.59^{\prime}\right.$ E) (Supplementary Figure S1). Cell morphology and physiological characteristics of strain Sph56 were highly similar to those of strains $\mathrm{Sph}^{\mathrm{T}}$ and OZ2. In addition, the 16S rRNA gene sequence determined for strain Sph56 (GenBank Accession number MH701868) displayed 99.5 $\%$ identity to the corresponding gene sequences from strains Sph1 $1^{\mathrm{T}}$ and OZ2 (Figure 1). Based on these data, strain Sph56 has also been identified as belonging to the species Methylovulum psychrotolerans.

For lipid analysis, the three strains were cultivated in NMS medium containing (in gram per liter) $\mathrm{MgSO}_{4}, 1 ; \mathrm{KNO}_{3}$, $1 ; \mathrm{CaCl}_{2}, 100 ; \mathrm{KH}_{2} \mathrm{PO}_{4}, 0.272 ; \mathrm{Na}_{2} \mathrm{HPO}_{4} \times 12 \mathrm{H}_{2} \mathrm{O}, 0.717$ with the addition of $0.1 \%(\mathrm{v} / \mathrm{v})$ of a trace elements stock solution containing (in grams per liter) EDTA, 5; $\mathrm{FeSO}_{4} .7 \mathrm{H}_{2} \mathrm{O}$, 2; $\mathrm{ZnSO}_{4} .7 \mathrm{H} 2 \mathrm{O}, 0.1 ; \mathrm{MnCl}_{2} .4 \mathrm{H}_{2} \mathrm{O}, 0.03 ; \mathrm{CoCl}_{2} .6 \mathrm{H}_{2} \mathrm{O}, 0.2$; $\mathrm{CuCl}_{2} .5 \mathrm{H}_{2} \mathrm{O}, 0.1 ; \mathrm{NiCl}_{2} .6 \mathrm{H}_{2} \mathrm{O}, 0.02$; and $\mathrm{Na}_{2} \mathrm{MoO}_{4}, 0.03$. The medium $\mathrm{pH}$ was 6.8 . The flasks of a total volume $500 \mathrm{ml}$ were filled to $20 \%$ capacity with NMS medium, sealed with rubber septa, and $\mathrm{CH}_{4}(30 \%, \mathrm{v} / \mathrm{v})$ was added to the headspace using syringes equipped with disposable filters $(0.22 \mu \mathrm{m})$. The cultures were grown in a Multitron Pro shaker incubator (Infors HT, Switzerland) at 4,10 and $20^{\circ} \mathrm{C}$, respectively, and were harvested in late exponential growth phase. 


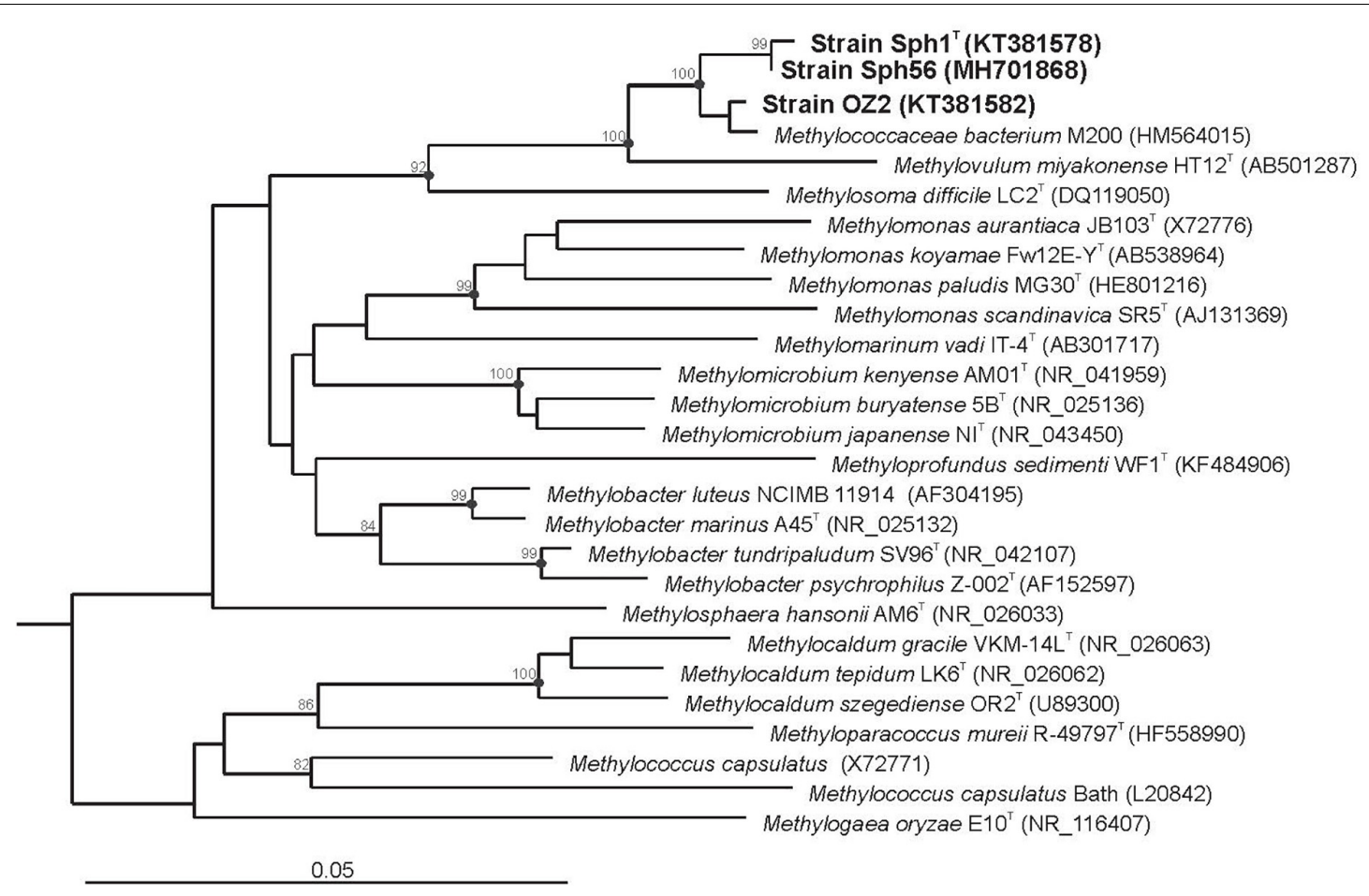

FIGURE 1 | 16S rRNA gene based neighbor-joining tree showing the phylogenetic position of strains Sph1 ${ }^{\top}$, OZ2 and Sph56 in relation to other members of the family Methylococcaceae. Bootstrap values (percentages of 1000 data resamplings) $>80 \%$ are shown. Black circles indicate that the corresponding nodes were also recovered in the maximum-likelihood and maximum- parsimony trees. The type II methanotrophs Methyloferula stellata AR4 (FR686343), Methylocella silvestris BL2 (AJ491847), Methylocapsa acidiphila B2 (AJ278726), Methylosinus sporium NCIMB 11126 (Y18946), Methylosinus trichosporium OB3b (Y18947) and Methylocystis parvus OBBP (Y18945) were used as an outgroup. Bar, 0.05 substitutions per nucleotide position.

\section{Measurements of Methane Oxidation Rates}

Prior to kinetic experiments, strains $\mathrm{Sph} 1^{\mathrm{T}}$, OZ2 and Sph56 were maintained in NMS medium at 4,10 and $20^{\circ} \mathrm{C}$, respectively, for one month, with regular transfers after 5-7 days. Methane oxidation rates were determined as described by Knief and Dunfield (2005). Briefly, the cells were counted, and the cultures

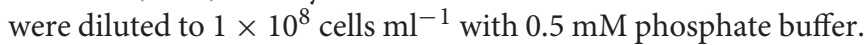
Chloramphenicol $\left(1.25 \mathrm{mg} \mathrm{l}^{-1}\right)$ was added to the experimental flasks to inhibit further cell growth. Aliquots $(10 \mathrm{ml})$ of cell suspensions were added to 500-ml flasks, which were sealed gas-tight with butyl rubber septa. Methane was added to final mixing ratios of $0.5 \%(\mathrm{v} / \mathrm{v})$. The flasks were fixed in a horizontal position on a rotary shaker with the temperature settings of 4,10 and $20^{\circ} \mathrm{C}$, respectively, and shaken at $110 \mathrm{rpm}$. The decrease of methane concentration in the headspace was followed over time using a gas chromatograph (Chromatec crystal 5000, Chromatec, Russia) equipped with a flame ionization detector. Methane oxidation rates were estimated by linear regressions of $\mathrm{CH}_{4}$ concentrations versus time.

\section{Fatty Acid Analysis}

For (bulk) fatty acid (FA) analysis, aliquots of the lyophilized cells from duplicate cultures were hydrolyzed by refluxing with $1.5 \mathrm{~N} \mathrm{HCl}: \mathrm{MeOH}$ solution for $3 \mathrm{~h}$. After adjustment of the $\mathrm{pH}$ to $4-5$ with a $2 \mathrm{~N} \mathrm{KOH} / \mathrm{MeOH}(1 / 1, \mathrm{v} / \mathrm{v})$ solution, extraction with dichloromethane (DCM) was carried out. The resulting extract was methylated with diazomethane in diethyl ether which was removed under a stream of $\mathrm{N}_{2}$. Before analysis an aliquot was treated with BSTFA in pyridine to derivatize alcohol groups and then brought to a final volume with ethyl acetate. FA methyl ester (FAME) identification was carried out using gas chromatography-mass spectrometry (Thermo Finnigan TRACE GC-MS). FAMEs were separated using a CP-SIL 5CB capillary column (length $25 \mathrm{~m} \times$ internal diameter $0.32 \mathrm{~mm}$, coating $0.12 \mu \mathrm{m}$ ) with the following oven conditions: initial temperature $70^{\circ} \mathrm{C}$, increasing to $130^{\circ} \mathrm{C}$ by $20^{\circ} \mathrm{C} \mathrm{min}^{-1}$, then increasing to $320^{\circ} \mathrm{C}$ by $4^{\circ} \mathrm{C} \mathrm{min}^{-1}$ and held for $10 \mathrm{~min}$. MS operating parameters were: electron multiplier $1663 \mathrm{~V}$; source temperature $250^{\circ} \mathrm{C}$; full scan $\mathrm{m} / z 50-800$; scan time $0.33 \mathrm{~s}$. MS data were acquired and processed using the Thermo Finnigan Xcalibur software. FAMEs were identified based on literature data and library mass spectra. Double bond positions were determined, where possible, using dimethyldisulfide (DMDS) derivatization of the FAMEs. To this end, extracts were derivatized in hexane $(100 \mu \mathrm{l})$ with DMDS (Merck $\geq 99 \% ; 100 \mu \mathrm{l})$ and $\mathrm{I}_{2} /$ ether $(60 \mathrm{mg}$ $\left.\mathrm{ml}^{-1} ; 20 \mu \mathrm{l}\right)$ and heated overnight at $40^{\circ} \mathrm{C}$. Hexane $(400 \mu \mathrm{l})$ was then added with $\mathrm{Na}_{2} \mathrm{~S}_{2} \mathrm{O}_{3}(5 \%$ aqueous solution; $200 \mu \mathrm{l})$ to deactivate the iodine. The hexane layer was removed, and the aqueous phase washed with hexane $(\times 2)$. The hexane layers were combined and analyzed by GC-MS as described above. 


\section{Hopanoid Analysis}

For the detection of the presence of biohopanoids, lyophilized cells were directly treated with periodic acid/sodium borohydride to convert bacteriohopanepolyols (BHPs) into GC-amenable hopanoid alcohols (hopanols) following procedure 2 described by Rohmer et al. (1984) with some modifications. Lyophilized cells (ca. $10 \mathrm{mg}$ ) were stirred with $1 \mathrm{ml}$ of a solution of periodic acid $(30 \mathrm{mg})$ in tetrahydrofuran/water $(8: 1, \mathrm{v} / \mathrm{v})$ at room temperature for $1 \mathrm{~h}$. After addition of water $(1 \mathrm{ml})$, the lipids were extracted three times with DCM $(2 \mathrm{ml})$, and the solution was dried over anhydrous $\mathrm{Na}_{2} \mathrm{SO}_{4}$, and evaporated to dryness. The residue was treated with $20 \mathrm{mg}$ of $\mathrm{NaBH}_{4}$ in $1 \mathrm{ml}$ methanol by stirring at room temperature for $1 \mathrm{~h}$. After addition of a solution of $\mathrm{KH}_{2} \mathrm{PO}_{4}$ $(1 \mathrm{ml}, 200 \mathrm{mM})$, the hopanols were extracted with DCM. The obtained reaction mixture was methylated with diazomethane and separated over a small column with activated $\mathrm{Al}_{2} \mathrm{O}_{3}$ into an apolar and a polar fraction using DCM and DCM-MeOH (2:1, $\mathrm{v} / \mathrm{v}$ ) as eluent, respectively. The polar fractions were silylated with $\mathrm{N}, \mathrm{O}$-bis(trimethylsilyl)-fluoroacetamide in pyridine at $60^{\circ} \mathrm{C}$ for $20 \mathrm{~min}$ and analyzed by GC and GC-MS. The distribution of hopanols was obtained by integration of the appropriate peaks. GC and GC-MS analysis was performed as described above for fatty acid analysis.

\section{Intact Polar Lipid Analysis}

The lyophilized biomass of Sph56 (single replicates from 20, 10 and $4^{\circ} \mathrm{C}$ ) was extracted using a modified Bligh-Dyer procedure (Bligh and Dyer, 1959). Briefly, the biomass was extracted ultrasonically three times for $10 \mathrm{~min}$ in a solvent mixture of methanol:dichloromethane:phosphate buffer (2:1:0.8, v:v). After sonication, the combined supernatants were phase-separated by adding additional dichloromethane and buffer to a final solvent ratio of 1:1:0.9 (v:v). The organic phase containing the IPLs was collected and the aqueous phase re-extracted three times with dichloromethane. Finally, the combined extract was dried under a stream of $\mathrm{N}_{2}$ gas. Before analysis the extract was redissolved in a mixture of MeOH:DCM (9:1, $\mathrm{v}: \mathrm{v})$ and aliquots were filtered through $0.45 \mu \mathrm{m}$ regenerated cellulose syringe filters ( $4 \mathrm{~mm}$ diameter; Grace Alltech, Deerfield, IL, United States). Analysis of extracts was carried out using an Ultra High Pressure Liquid Chromatography-High Resolution Mass Spectrometry (UHPLC-HRMS) according to the reversed phase method of Wörmer et al. (2013) with some modifications. We used an Ultimate 3000 RS UHPLC, equipped with thermostatted auto-injector and column oven, coupled to a Q Exactive Orbitrap MS with Ion Max source with heated electrospray ionization (HESI) probe (Thermo Fisher Scientific, Waltham, MA, United States). Separation was achieved on an Acquity BEH C18 column (Waters, $2.1 \times 150 \mathrm{~mm}$, $1.7 \mu \mathrm{m}$ ) maintained at $30^{\circ} \mathrm{C}$. The eluent composition was (A) $\mathrm{MeOH}: \mathrm{H}_{2} \mathrm{O}$ :formic acid:14.8 $\mathrm{M} \mathrm{NH}_{3 \mathrm{aq}}$ (85:15:0.12:0.04 [v:v:v:v]) and (B) IPA:MeOH:formic acid:14.8 $\mathrm{M} \mathrm{NH}_{3 \text { aq }}$ (50:50:0.12:0.04 [v:v:v:v]). The elution program was: $95 \%$ A for $3 \mathrm{~min}$, followed by a linear gradient to $40 \% \mathrm{~A}$ at $12 \mathrm{~min}$ and then to $0 \% \mathrm{~A}$ at $50 \mathrm{~min}$, this was maintained until $80 \mathrm{~min}$. The flow rate was $0.2 \mathrm{~mL} \mathrm{~min}{ }^{-1}$. Positive ion ESI settings were: capillary temperature, $300^{\circ} \mathrm{C}$; sheath gas $\left(\mathrm{N}_{2}\right)$ pressure, 40 arbitrary units (AU); auxiliary gas $\left(\mathrm{N}_{2}\right)$ pressure, $10 \mathrm{AU}$; spray voltage, $4.5 \mathrm{kV}$; probe heater temperature, $50^{\circ} \mathrm{C}$; S-lens $70 \mathrm{~V}$. Target lipids were analyzed with a mass range of $\mathrm{m} / \mathrm{z} 350-2000$ (resolving power $70,000 \mathrm{ppm}$ at $\mathrm{m} / \mathrm{z} 200$ ), followed by datadependent tandem $\mathrm{MS}^{2}$ (resolving power 17,500 ppm), in which the ten most abundant masses in the mass spectrum were fragmented successively (stepped normalized collision energy 15, 22.5, 30; isolation width, $1.0 \mathrm{~m} / z$ ). The Q Exactive was calibrated within a mass accuracy range of $1 \mathrm{ppm}$ using the Thermo Scientific Pierce LTQ Velos ESI Positive Ion Calibration Solution. During analysis dynamic exclusion was used to temporarily exclude masses (for $6 \mathrm{~s}$ ) in order to allow selection of less abundant ions for $\mathrm{MS}^{2}$. The relative abundance of peak areas does not necessarily reflect the actual relative abundance of the different compounds, however, this method allows for comparison between the samples analyzed in this study. The IPL groups were identified through comparison with fragmentation patterns of authentic standards, as described in Brandsma et al. (2012). The chain length and number of double bond equivalents of the IPL-bound fatty acids (FA) were determined by either the fragment ions or neutral losses diagnostic for FAs obtained in the $\mathrm{MS}^{2}$ spectra (Brügger et al., 1997; Brandsma et al., 2012). The peak areas were determined from extracted ion chromatograms of the dominant ion formed for each individual IPL species.

\section{Genomic Analyses}

The sequences of putative fatty acid desaturase (POZ50891.1) and sterol desaturase (POZ53527.1) of M. psychrotolerans Sph1 $1^{\mathrm{T}}$ (GenBank accession no. PGFZ01000000; Oshkin et al., 2018) were identified with the PSI-BLAST algorithm using the (5) fatty acid desaturase (5-Des; O34653) from Bacillus subtilis and sterol desaturase ERG3 (P32353) from Saccharomyces cerevisiae as queries. The sequences were aligned with MAFFT (Katoh and Standley, 2013) in the http://www.ebi.ac.uk/Tools server (Chojnacki et al., 2017) using the BLOSUM62 substitution matrix with a gap open penalty of 1 and a gap extension penalty of 0.05 . The alignment was edited with Jalview (Waterhouse et al., 2009) and the presence of conserved histidine rich motifs was verified.

\section{RESULTS AND DISCUSSION}

\section{Methane Oxidation at Different Temperatures}

The decline of $\mathrm{CH}_{4}$ concentration in the experimental flasks incubated at different temperatures is shown in Figure 2. The highest methane oxidizing activities $\left(6.9-7.4 \times 10^{-15} \mathrm{~mol}\right.$ $\mathrm{CH}_{4} \mathrm{~h}^{-1}$ cell $^{-1}$ ) were observed at $20^{\circ} \mathrm{C}$, which is consistent with the original description of Methylovulum psychrotolerans as showing growth optimum at $20-25^{\circ} \mathrm{C}$ (Oshkin et al., 2016). Methane oxidation rates measured for these methanotrophs at $10^{\circ} \mathrm{C}$ were in the range 3.9-4.4 $\times 10^{-15} \mathrm{~mol} \mathrm{CH}_{4} \mathrm{~h}^{-1} \mathrm{cell}^{-1}$, thus constituting $57-60 \%$ of the corresponding activities at $20^{\circ} \mathrm{C}$. As a rule, lowering the temperature by $10^{\circ} \mathrm{C}$ induces a two- to fourfold decrease in enzyme activity (i.e., the socalled Q10 value; Feller and Gerday, 2003). Methanotrophs 
examined in our study, therefore, were relatively resistant to decrease in $10^{\circ} \mathrm{C}$ away from their temperature optimum. The methane oxidation rates determined at $4^{\circ} \mathrm{C}$ were in the range 2.0-2.3 $\times 10^{-15} \mathrm{~mol} \mathrm{CH}_{4} \mathrm{~h}^{-1}$ cell $^{-1}$, which is twice lower as those at $10^{\circ} \mathrm{C}$ (Table 1). All three strains of the species Methylovulum psychrotolerans, therefore, could be regarded as psychrotolerant mesophiles capable of oxidizing methane at low temperatures, down to $4^{\circ} \mathrm{C}$. The growth rates, doubling times and the growth dynamics of the three strains at the three temperatures are given in Supplementary Tables S1, S2 and Figure S2.

\section{The Lipid Distribution in Methylovulum psychrotolerans}

The three M. psychrotolerans strains examined in duplicate contained nine bulk fatty acids (FAs): $\mathrm{C}_{14: 1 \omega 7}, \mathrm{C}_{14: 0}, \mathrm{C}_{15: 0}$, $\mathrm{C}_{16: 1 \omega 8 \mathrm{c}}, \mathrm{C}_{16: 1 \omega 7 \mathrm{c}}, \mathrm{C}_{16: 1 \omega 6 \mathrm{c}}, \mathrm{C}_{16: 1 \omega 5 \mathrm{tr}}, \mathrm{C}_{16: 0}, \beta \mathrm{OH}-\mathrm{C}_{16: 0} . \mathrm{C}_{16: 1 \omega 8 \mathrm{c}}$ was previously considered unique to type I methanotrophs (Sundh et al., 2005; Bowman, 2006) but is now known to also be produced by type II methanotrophs (Dedysh et al., 2007; Bodelier et al., 2009). However $\mathrm{C}_{16: 1 \omega 8 \mathrm{c}}$ has been reported as the dominant FA in Methylomonas methanica, Methylomonas fodinarum and Methylomonas aurantiaca (Bowman et al., 1991). $C_{16: 1 \omega 7 c}$ is a more cosmopolitan bacterial FA, not specific to methanotrophs. Another species of the genus Methylovulum, Methylovulum miyakonense, has been reported to have a similar FA distribution to that of $M$. psychrotolerans (Oshkin et al., 2016).
Three Bligh-Dyer extracts of one strain (Sph56), grown at 20,10 and $4^{\circ} \mathrm{C}$, were examined for their intact polar lipid (IPL) distribution. The IPLs detected had either phosphatidylglycerol (PG) or phosphatidylethanolamine (PE) head groups, with a range of FA combinations (Table 2). The head group composition was very similar to that of a range of methanotrophic bacteria described previously (Fang et al., 2000). Additionally, a lyso-PE, (PE in which one of the FA chains is not present) was detected. The majority of IPLs were PE, with the ratio of PG/PE as 0.2. Where possible, the chain length and number of double bond equivalents of the IPL-bound FAs were determined by either the fragment ions diagnostic for FAs obtained in the $\mathrm{MS}^{2}$ (Brügger et al., 1997; Brandsma et al., 2012). Where this was not possible (cf. Table 2) an informed estimation of the FAs associated with each IPL was made. In addition to the $\mathrm{C}_{14: 0}, \mathrm{C}_{14: 1}, \mathrm{C}_{15: 0}, \mathrm{C}_{16: 0}$ and $\mathrm{C}_{16: 1}$ detected in the bulk FAs, $\mathrm{C}_{15: 1}$ and $\mathrm{C}_{16: 2}$ were also detected. The $\mathrm{C}_{15: 1}$ and $\mathrm{C}_{16: 2}$ were not detected in the bulk FAs, probably due to their very low abundance and differences in the limit of detection for the different analytical methods applied.

Six hopanols formed by Rohmer degradation of BHPs were identified across the duplicates of the three strains (see Figure 3 for structures): $\mathrm{C}_{30: 0}$ (homohopanol), $\mathrm{C}_{30: 1}$ (homohop-11-enol), $\mathrm{C}_{31: 0}$ (homohopan-31-ol), $\mathrm{C}_{31: 1}$ (homohop-11-en-31-ol), $\mathrm{C}_{32: 0}$ (bis-homohopan-32-ol) and $\mathrm{C}_{32: 1}$ (bis-homohop-11-en-32-ol). The double bond position in the three unsaturated hopanols was confirmed as $\Delta^{11}$ by both the absence of $\mathrm{m} / z \quad 119$ ion peaks and the presence of $\mathrm{M}$ - $192 \mathrm{Da}$ ion peaks in their EI mass spectra (Cvejic et al., 2000a,b; Talbot et al., 2007b; van Winden et al., 2012b). These hopanols are the

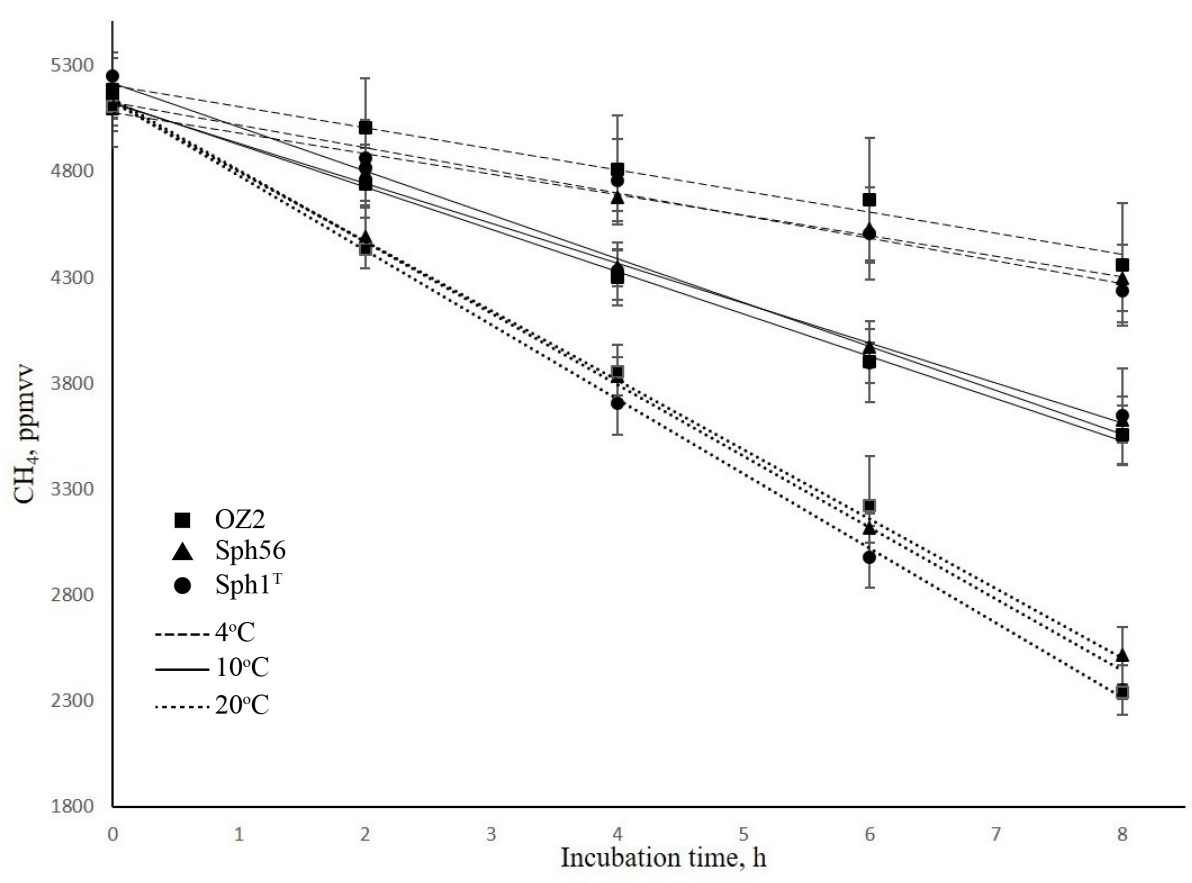

FIGURE 2 | Dynamics of methane concentration in the experimental flasks with strains Sph1 ${ }^{\top}$ (circles), OZ2 (squares), and Sph56 (triangles) at different incubation temperatures. Dotted, solid and dashed lines indicate incubations at 20,10 and $4^{\circ} \mathrm{C}$, respectively. The linear decline in methane concentration indicates that cell growth did not occur during the incubation period. Data are means of triplicate. 
TABLE 1 | Methane oxidation rates ( $\times 10^{-15} \mathrm{~mol} \mathrm{CH}_{4} \mathrm{~h}^{-1}$ cell-1) of Methylovulum psychrotolerans strains Sph1 ${ }^{\top}$, OZ2, and Sph56 measured at 4, 10 and $20^{\circ} \mathrm{C}$ and calculated per cell.

\begin{tabular}{lccc}
\hline Strain & \multicolumn{3}{c}{ Temperature $\left({ }^{\circ} \mathbf{C}\right)$} \\
\cline { 2 - 4 } & $\mathbf{2 0}$ & $\mathbf{1 0}$ & $\mathbf{4}$ \\
\hline Sph1 $^{\top}$ & $7.40 \pm 0.39$ & $4.40 \pm 0.36$ & $2.30 \pm 0.17$ \\
OZ2 & $7.10 \pm 0.35$ & $4.20 \pm 0.34$ & $2.10 \pm 0.31$ \\
Sph56 & $6.90 \pm 0.24$ & $3.90 \pm 0.23$ & $2.00 \pm 0.26$ \\
\hline
\end{tabular}

TABLE 2 | Relative percentage of intact polar lipids in Methylovulum psychrotolerans (strain Sph56) measured at 4, 10 and $20^{\circ} \mathrm{C}$.

\begin{tabular}{|c|c|c|c|c|}
\hline & & $20^{\circ} \mathrm{C}$ & $10^{\circ} \mathrm{C}$ & $4^{\circ} \mathrm{C}$ \\
\hline \multirow[t]{28}{*}{ IPLS } & Lyso-PE 16:1* & 1.2 & 4.3 & 2.2 \\
\hline & PE 28:0 (14:0,14:0)* & 1.4 & 1.0 & 0.8 \\
\hline & PE 28:1 (14:0,14:1) & 2.3 & 6.7 & 6.3 \\
\hline & PE $28: 2(14: 1,14: 1)^{*}$ & 0.0 & 0.3 & 0.3 \\
\hline & PE 29:0 (14:0, 15:0)* & 0.2 & 0.3 & 0.2 \\
\hline & PE 29:1 (14:1, 15:0)* & 0.3 & 1.2 & 1.3 \\
\hline & PE 30:0 (14:0, 16:0)* & 2.2 & 0.5 & 0.4 \\
\hline & PE 30:1 (14:0, 16:1)* & 14 & 14 & 13 \\
\hline & PE $30: 2(14: 1,16: 1)^{*}$ & 3.6 & 14 & 16 \\
\hline & PE 31:0 (15:0, 16:0)* & 0.3 & 0.0 & 0.0 \\
\hline & PE 31:1 (15:0, 16:1)* & 2.5 & 2.6 & 3.0 \\
\hline & PE $31: 2(15: 1,16: 1)^{*}$ & 0.5 & 1.6 & 2.0 \\
\hline & PE 32:0 (16:0, 16:0)* & 2.2 & 0.1 & 0.1 \\
\hline & PE 32:1 (16:0, 16:1)* & 21 & 5.8 & 5.8 \\
\hline & PE 32:2 (16:1, 16:1)* & 33 & 33 & 33 \\
\hline & PE 32:3 (16:1, 16:2)* & 0.0 & 0.1 & 0.1 \\
\hline & PG 28:0 (14:0,14:0)* & 0.2 & 0.2 & 0.1 \\
\hline & PG 28:1 (14:0,14:1) & 0.2 & 0.8 & 0.8 \\
\hline & PG 29:1 (14:1, 15:0) & 0.0 & 0.1 & 0.1 \\
\hline & PG 30:0 (14:0, 16:0)* & 0.5 & 0.1 & 0.1 \\
\hline & PG 30:1 (14:0, 16:1)* & 2.5 & 3.3 & 2.9 \\
\hline & PG $30: 2(14: 1,16: 1)^{*}$ & 0.2 & 2.0 & 2.4 \\
\hline & PG $31: 1(15: 0,16: 1)^{*}$ & 0.2 & 0.1 & 0.2 \\
\hline & PG $31: 2(15: 1,16: 1)^{*}$ & 0.0 & 0.1 & 0.1 \\
\hline & PG 32:0 (16:0, 16:0)* & 0.4 & 0.0 & 0.0 \\
\hline & PG 32:1 (16:0, 16:1)* & 4.3 & 0.8 & 0.9 \\
\hline & PG $32: 2(16: 1,16: 1)^{*}$ & 6.8 & 7.2 & 8.1 \\
\hline & PG/PE ratio & 0.2 & 0.2 & 0.2 \\
\hline \multirow[t]{4}{*}{ IPL-bound FAs } & Total $\mathrm{C}_{16}$ & 82 & 71 & 70 \\
\hline & Total $\mathrm{C}_{15}$ & 2.0 & 3.0 & 3.5 \\
\hline & Total $\mathrm{C}_{14}$ & 16 & 26 & 26 \\
\hline & Total unsaturated & 69 & 80 & 81 \\
\hline
\end{tabular}

*IPL-bound FA combination confirmed by $\mathrm{MS}^{2}$ diagnostic fragment ions.

product of bacteriohopanepolyols (BHPs): tetrafunctionalised BHPs give $\mathrm{C}_{32}$ hopanols, pentafunctionalised $\mathrm{BHPs}$ give $\mathrm{C}_{31}$ hopanols and hexafunctionalised $\mathrm{BHPs}$ give $\mathrm{C}_{30}$ hopanols. Diplopterol, not formed by degradation of a BHP, was also detected in the three strains, although not in the cultures grown at $20^{\circ} \mathrm{C}$. The ratio of diplopterol to the sum of the six hopanols formed by Rohmer degradation of BHPs was on average at $0.1 \pm 0.0$ at both 10 and $4^{\circ} \mathrm{C}$ (Table 3).
The three strains exhibited similar hopanol distributions to each other (see Table 3 for data for the individual strains), although to a lesser degree than with the FAs. Tetra, penta and hexafunctionalised BHPs, from which the hopanols analyzed in this studied are derived, have been described across a range of methanotrophs, including from the genera Methylomarinum, Methylomarinovum, Methylomicrobium, (Rush et al., 2016), Methylomonas, Methylosinus, Methylocella, Methylacidiphilium (van Winden et al., 2012b), Methylobacter (Osborne et al., 2017) as well as in a Methylovulum-like strain M200 (van Winden et al., 2012b). Unsaturated aminotriol and aminotetrol BHPs have only to date been described in a Methylovulum-like strain M200 (van Winden et al., 2012b) which suggests that they are characteristic of the Methylovulum genera. The unsaturated aminopentol BHP has been described in the Methylovulum-like strain M200 and a Methylomonas-like strain (van Winden et al., 2012b) as well as in three strains of Methylobacter (Osborne et al., 2017). Additionally, the thermophilic Methylocaldum szegediense was found to contain a $\Delta^{11}$ unsaturated aminopentol BHP in combination with a methyl group at the $3 \beta$ position (Cvejic et al., 2000a). Hopanoids with $\Delta^{11}$ unsaturations have also been identified in a range of acetic acid bacteria (Rohmer and Ourisson, 1976; Simonin et al., 1994; Herrmann et al., 1996).

\section{Changes in the Lipid Distribution With Changing Growth Temperature}

The bulk-FA distributions of the three strains were so similar to each other at each temperature, that we discuss them further only as an average of the 6 cultures (three strains in duplicate). For the data of the individual strains see Table 4 and Figure 4 . The majority of bulk-FA was $\mathrm{C}_{16}$ fatty acids. At the $20^{\circ} \mathrm{C}$ temperature optimum, $91 \pm 0.5 \%$ of bulk-FAs were $C_{16}$, while at the two lower growth temperatures this percentage decreased slightly, to $86 \pm 0.8 \%$ at $10^{\circ} \mathrm{C}$ and $87 \pm 1.5 \%$ at $4^{\circ} \mathrm{C}$. There was a concomitant increase in the $\mathrm{C}_{14}$ bulk-FA with decreasing temperature, from $8.3 \pm 0.4 \%$ at $20^{\circ} \mathrm{C}$, to $14 \pm 0.7 \%$ at $10^{\circ} \mathrm{C}$ and $13 \pm 1.5 \%$ at $4^{\circ} \mathrm{C}$. The single $\mathrm{C}_{15}$ bulk-FA was a minor component and did not change with temperature $(0.5 \pm 0.0 \%$ at $20^{\circ} \mathrm{C}, 0.5 \pm 0.1 \%$ at $10^{\circ} \mathrm{C}$ and $0.5 \pm 0.1 \%$ at $\left.4^{\circ} \mathrm{C}\right)$. The total percent of unsaturated bulk-FA (again an average of the 6 cultures, see Table 4 for data for the individual strains) increased with decreasing growth temperature. While it was $79 \pm 2.0 \%$ at the $20^{\circ} \mathrm{C}$ optimum temperature, it had increased to $87 \pm 3.1 \%$ at $10^{\circ} \mathrm{C}$ and $89 \pm 0.9$ at $4^{\circ} \mathrm{C}$. The changes in total IPL-bound FAs with growth temperature were very similar to those of the bulk-FAs: the majority of fatty acids were $\mathrm{C}_{16}$ fatty acids, $82 \%$ at $20^{\circ} \mathrm{C}$ which decreased to $71 \%$ at $10^{\circ} \mathrm{C}$ and $70 \%$ at $4^{\circ} \mathrm{C}$. As with the bulk-FAs there was a concomitant increase in the IPL-bound $\mathrm{C}_{14}$ fatty acids with decreasing temperature, from $16 \%$ at $20^{\circ} \mathrm{C}$, to $26 \%$ at $10^{\circ} \mathrm{C}$ and $26 \%$ at $4^{\circ} \mathrm{C}$. IPLbound $\mathrm{C}_{15}$ fatty acids were a minor component and changed only slightly with temperature $\left(2.0 \%\right.$ at $20^{\circ} \mathrm{C}, 3.0 \%$ at $10^{\circ} \mathrm{C}$ and $3.5 \%$ at $4^{\circ} \mathrm{C}$ ). The total percent of unsaturated IPL-bound FAs behaved similarly, to the bulk-FAs: it increased with decreasing growth temperature, from $69 \%$ at the $20^{\circ} \mathrm{C}$ to $80 \%$ at $10^{\circ} \mathrm{C}$ and 81 at $4^{\circ} \mathrm{C}$. 


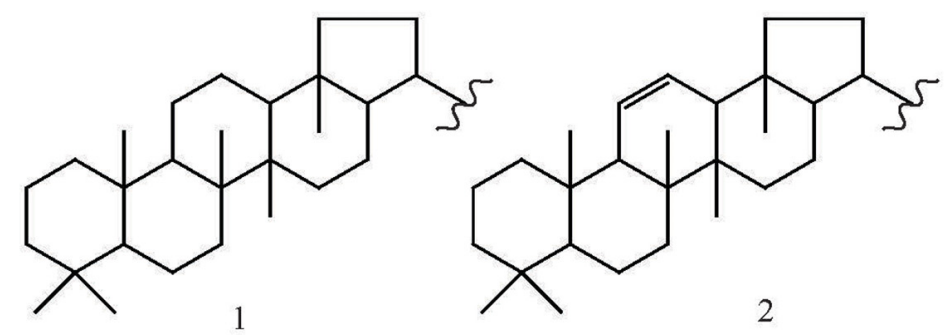

1<smiles>CC(C)(C)O</smiles>

a<smiles>CC(C)CO</smiles>

b<smiles>CC(C)CCO</smiles>

$\mathrm{c}$<smiles>CC(C)CCCO</smiles>

d

\section{Hopanols formed by Rohmer degradation}

1a - Diplopterol

1b - C30:0 (homohopanol)

2b - C30:1 (homohop-11-enol)

1c - C31:0 (homohopan-31-ol)

2c - C31:1 (homohop-11-en-31-ol)

1d - C32:0 (bis-homohopan-32-ol)

2d - C32:1 (bis-homohop-11-en-32-ol)

FIGURE 3 | Structures of diplopterol and the hopanols formed by Rohmer degradation of bacteriohopanepolyols (BHPs) identified across the three Methylovulum psychrotolerans strains: $\mathrm{C}_{30: 0}$ (homohopanol), $\mathrm{C}_{30: 1}$ (homohop-11-enol), $\mathrm{C}_{31: 0}$ (homohopan-31-ol), $\mathrm{C}_{31: 1}$ (homohop-11-en-31-ol), $\mathrm{C}_{32: 0}$ (bis-homohopan-32-ol) and $\mathrm{C}_{32: 1}$ (bis-homohop-11-en-32-ol).

Previous studies have noted an increase of either more polar IPLs or more polar carotenoids in the membrane in adaption to decreased temperature for the psychrophilic Clostridium psychromophilum (Guan et al., 2013) and the psychrotolerant bacteria Micrococcus roseus (Chattopadhyay et al., 1997) and Sphingobacterium antarcticus (Jagannadham et al., 2000). However, in this study the IPL head group composition, and hence its polarity did not change with temperature: the ratio of PG to PE was 0.2 at all temperatures.

Another bulk-FA change with decreasing growth temperature was a relative increase in the $\beta$-hydroxy $\mathrm{FA}, \beta \mathrm{OH}-\mathrm{C}_{16: 0}$. The ratio of $\beta \mathrm{OH}-\mathrm{C}_{16: 0}$ to $\mathrm{C}_{16: 0}$ increased as growth temperature decreased, from 0.2 at $20^{\circ} \mathrm{C}$, to 0.9 at both 10 and $4^{\circ} \mathrm{C}$ (Table 4). $\beta \mathrm{OH}-\mathrm{C}_{16: 0}$ has been detected in a range of methanotrophic bacteria (Bowman et al., 1991) and the source of many $\beta$-hydroxy FAs has been identified as the lipid A component of lipopolysaccharides (Wollenweber and Rietschel, 1990), which are a major constituent of the outer membrane of Gram-negative bacteria (Wollenweber and Rietschel, 1990; Keinänen et al., 2003). $\beta$-hydroxy FAs have been applied as biomarkers for Gram-negative bacteria in environmental studies (Klok et al., 1988; Wakeham et al., 2003; Lee et al., 2004; Wang et al., 2016) and the effect of temperature on the relative distribution of $\beta$-hydroxy FAs has been studied in the natural environment (Wang et al., 2016). Marr and Ingraham (1962) showed an increase in the relative percent of $\beta \mathrm{OH}-\mathrm{C}_{14: 0}$ in Escherichia coli from 6.9 to $12 \%$ as the growth temperature decreased from 25 to $10^{\circ} \mathrm{C}$.

The majority of the hopanols at the temperature optimum of $20^{\circ} \mathrm{C}$ were $\mathrm{C}_{32: 0}(36 \pm 5.2 \%)$. The major change between the 20 and $10^{\circ} \mathrm{C}$ was that the relative percentage of $\mathrm{C}_{32: 1}$ increased significantly, from $11 \pm 1.1 \%$ to $45 \pm 4.6 \%$. It was slightly lower at $4^{\circ} \mathrm{C}(34 \pm 7.8 \%)$ but still significantly higher than at $20^{\circ} \mathrm{C}$. This relative increase was countered by concomitant decreases in the other hopanols (Table 3). As was seen with the fatty acids, the percent of unsaturated hopanols increased for the cultures grown below the optimum growth temperature: from $27 \pm 4.1 \%$ at $20^{\circ} \mathrm{C}$, to $58 \pm 2.5 \%$ at $10^{\circ} \mathrm{C}$ and $49 \pm 7.7 \%$ at $4^{\circ} \mathrm{C}$. The hopanols were also examined in terms of total $\mathrm{C}_{30}$ (saturated and unsaturated), $\mathrm{C}_{31}$ and $\mathrm{C}_{32}$. On average, the $\mathrm{C}_{30}$ sum decreased from $32 \pm 10$ at $20^{\circ} \mathrm{C}$ to $17 \pm 6.0$ at $10^{\circ} \mathrm{C}$ and $18 \pm 4.2$ at $4^{\circ} \mathrm{C}$. The total $\mathrm{C}_{31}$ also decreased from $22 \pm 5.7 \%$ at $20^{\circ} \mathrm{C}$ to $7.4 \pm 1.4 \%$ at $10^{\circ} \mathrm{C}$ and $14 \pm 2.8 \%$ at $4^{\circ} \mathrm{C}$. Consequently, there was an increase in the total $\mathrm{C}_{32}$, from $46 \pm 5.0 \%$ at $20^{\circ} \mathrm{C}$ to $76 \pm 6.2 \%$ at $10^{\circ} \mathrm{C}$ and $69 \pm 5.2 \%$ at $4^{\circ} \mathrm{C}$.

Overall, there was an increase in the percent of unsaturated hopanols as temperature decreased, along with a decrease in both the total $\mathrm{C}_{30}$ and $\mathrm{C}_{31}$ and concomitant increase in $\mathrm{C}_{32}$. In a mesocosm study of symbiotic methanotrophs in Sphagnum moss (van Winden, 2011; van Winden et al., 2012a), no unsaturated BHPs were reported, however, the relative percentage of aminotriol BHP (corresponding to $\mathrm{C}_{32}$ hopanol) increased as temperature decreased (from 25 to $5^{\circ} \mathrm{C}$ ), while both aminotetrol BHP (corresponding to $\mathrm{C}_{31}$ hopanol) and aminopentol BHP (corresponding to $\mathrm{C}_{30}$ hopanol) decreased. Similarly, Osborne et al. (2017) also reported changes in the BHP distribution with temperature in methane-amended aerobic river-sediment incubations. In those temperature treatments relevant to this study, it was shown that with decreasing temperature (from $40^{\circ} \mathrm{C}$ to $4^{\circ} \mathrm{C}$ ) there was also an increase in the relative percentage of aminotriol BHP (corresponding to $\mathrm{C}_{32}$ hopanol), while aminopentol $\mathrm{BHP}$ decreased and aminotetrol BHP remained constant (Osborne et al., 2017). In contrast, Jahnke et al. (1999) reported that for a psychrotolerant 
TABLE 3 | Relative percentage of hopanols (not including diplopterol) formed by Rohmer degradation (RD) in Methylovulum psychrotolerans strains Sph1 ${ }^{\top}$, OZ2, and Sph56 measured at 4,10 and $20^{\circ} \mathrm{C}$.

\begin{tabular}{|c|c|c|c|c|}
\hline Strain & & $20^{\circ} \mathrm{C}$ & $10^{\circ} \mathrm{C}$ & $4^{\circ} \mathrm{C}$ \\
\hline \multirow[t]{11}{*}{ Av. 3 strains } & $\mathrm{C}_{30: 1}$ & $13 \pm 4.6$ & $10 \pm 2.7$ & $10 \pm 2.1$ \\
\hline & $\mathrm{C}_{30: 0}$ & $19 \pm 6.5$ & $6.9 \pm 3.3$ & $7.2 \pm 2.3$ \\
\hline & $\mathrm{C}_{31: 1}$ & $4.1 \pm 17$ & $3.1 \pm 0.7$ & $4.3 \pm 1.6$ \\
\hline & $\mathrm{C}_{31: 0}$ & $18 \pm 4.0$ & $4.2 \pm 1.1$ & $9.5 \pm 2.8$ \\
\hline & $\mathrm{C}_{32: 1}$ & $11 \pm 1.1$ & $45 \pm 4.6$ & $34 \pm 7.8$ \\
\hline & $\mathrm{C}_{32: 0}$ & $36 \pm 5.2$ & $31 \pm 1.9$ & $34 \pm 3.4$ \\
\hline & Total $\mathrm{C}_{30}$ & $32 \pm 10$ & $17 \pm 6.0$ & $18 \pm 4.2$ \\
\hline & Total $\mathrm{C}_{31}$ & $22 \pm 5.7$ & $7.4 \pm 1.4$ & $14 \pm 2.8$ \\
\hline & Total $\mathrm{C}_{32}$ & $46 \pm 5.0$ & $76 \pm 6.2$ & $69 \pm 5.2$ \\
\hline & Total unsaturated & $27 \pm 4.1$ & $58 \pm 2.5$ & $49 \pm 7.7$ \\
\hline & Ratio diplopterol/ $\Sigma$ RD hopanols & nd & $0.1 \pm 0.0$ & $0.1 \pm 0.0$ \\
\hline \multirow[t]{11}{*}{$\operatorname{Sph}^{\top}$} & $\mathrm{C}_{30: 1}$ & $18 \pm 0.8$ & $10 \pm 0.9$ & $13 \pm 1.2$ \\
\hline & $\mathrm{C}_{30: 0}$ & $22 \pm 0.6$ & $6.3 \pm 0.5$ & $8.5 \pm 0.3$ \\
\hline & $\mathrm{C}_{31: 1}$ & $3.4 \pm 0.0$ & $2.7 \pm 0.5$ & $2.9 \pm 0.3$ \\
\hline & $\mathrm{C}_{31: 0}$ & $16 \pm 0.4$ & $3.5 \pm 1.1$ & $8.6 \pm 2.6$ \\
\hline & $\mathrm{C}_{32: 1}$ & $12 \pm 0.2$ & $47 \pm 1.7$ & $34 \pm 3.6$ \\
\hline & $\mathrm{C}_{32: 0}$ & $30 \pm 1.4$ & $30 \pm 1.3$ & $34 \pm 2.3$ \\
\hline & Total $\mathrm{C}_{30}$ & $39 \pm 1.4$ & $16 \pm 1.4$ & $21 \pm 1.0$ \\
\hline & Total $\mathrm{C}_{31}$ & $19 \pm 0.4$ & $6.2 \pm 1.6$ & $12 \pm 2.2$ \\
\hline & Total $\mathrm{C}_{32}$ & $41 \pm 0.9$ & $77 \pm 3.0$ & $67 \pm 1.3$ \\
\hline & Total unsaturated & $33 \pm 0.9$ & $60 \pm 0.3$ & $49 \pm 5.1$ \\
\hline & Ratio diplopterol/ $\Sigma$ RD hopanols & nd & $0.1 \pm 0.0$ & $0.1 \pm 0.0$ \\
\hline \multirow[t]{11}{*}{$\mathrm{OZ2}$} & $\mathrm{C}_{30: 1}$ & $13 \pm 0.4$ & $13 \pm 0.4$ & $11 \pm 0.5$ \\
\hline & $\mathrm{C}_{30: 0}$ & $25 \pm 0.3$ & $11 \pm 0.2$ & $8.7 \pm 0.1$ \\
\hline & $\mathrm{C}_{31: 1}$ & $2.8 \pm 0.1$ & $2.7 \pm 0.1$ & $3.8 \pm 0.2$ \\
\hline & $\mathrm{C}_{31: 0}$ & $15 \pm 0.3$ & $5.1 \pm 1.5$ & $12 \pm 0.1$ \\
\hline & $\mathrm{C}_{32: 1}$ & $9.2 \pm 0.3$ & $39 \pm 1.0$ & $26 \pm 0.6$ \\
\hline & $\mathrm{C}_{32: 0}$ & $36 \pm 0.5$ & $29 \pm 0.6$ & $38 \pm 0.2$ \\
\hline & Total $\mathrm{C}_{30}$ & $38 \pm 0.6$ & $24 \pm 0.1$ & $19 \pm 0.5$ \\
\hline & Total $\mathrm{C}_{31}$ & $17 \pm 0.2$ & $7.8 \pm 1.4$ & $16 \pm 0.1$ \\
\hline & Total $\mathrm{C}_{32}$ & $45 \pm 0.8$ & $68 \pm 1.6$ & $64 \pm 0.3$ \\
\hline & Total unsaturated & $25 \pm 0.0$ & $55 \pm 0.7$ & $41 \pm 0.3$ \\
\hline & Ratio diplopterol/ $\Sigma$ RD hopanols & nd & $0.1 \pm 0.0$ & $0.1 \pm 0.0$ \\
\hline \multirow[t]{11}{*}{ Sph56 } & $\mathrm{C}_{30: 1}$ & $7.4 \pm 0.3$ & $7.2 \pm 0.8$ & $8.2 \pm 1.3$ \\
\hline & $\mathrm{C}_{30: 0}$ & $11 \pm 0.0$ & $3.6 \pm 0.4$ & $4.3 \pm 1.0$ \\
\hline & $\mathrm{C}_{31: 1}$ & $6.3 \pm 0.5$ & $3.9 \pm 0.4$ & $6.1 \pm 1.4$ \\
\hline & $\mathrm{C}_{31: 0}$ & $23 \pm 0.4$ & $4.2 \pm 0.4$ & $7.4 \pm 1.9$ \\
\hline & $\mathrm{C}_{32: 1}$ & $11 \pm 0.1$ & $48 \pm 1.1$ & $43 \pm 3.7$ \\
\hline & $\mathrm{C}_{32: 0}$ & $41 \pm 1.2$ & $33 \pm 1.0$ & $31 \pm 1.9$ \\
\hline & Total $\mathrm{C}_{30}$ & $19 \pm 0.4$ & $11 \pm 1.2$ & $12 \pm 2.3$ \\
\hline & Total $\mathrm{C}_{31}$ & $29 \pm 1.0$ & $8.1 \pm 0.8$ & $13 \pm 3.3$ \\
\hline & Total $\mathrm{C}_{32}$ & $34 \pm 0.4$ & $53 \pm 0.7$ & $50 \pm 1.8$ \\
\hline & Total unsaturated & $25 \pm 0.8$ & $60 \pm 0.1$ & $57 \pm 0.9$ \\
\hline & Ratio diplopterol/ $\Sigma$ RD hopanols & nd & $0.1 \pm 0.0$ & $0.1 \pm 0.0$ \\
\hline
\end{tabular}

methanotroph (thought to be Methylomonas methanica) the relative percentage of $\mathrm{C}_{32}$ hopanol remained the same as temperature decreased, while the $\mathrm{C}_{30}$ hopanol increased and the $\mathrm{C}_{31}$ hopanol decreased. Overall, based on our results and the limited reports in the literature, it would seem that methanotrophic bacteria adapt their BHP distribution to adapt to colder temperatures, by increasing the relative amount of tetrafunctionalised BHPs (either in the saturated or unsaturated form).

In all three $M$. psychrotolerans strains diplopterol was not detected in the cultures grown at $20^{\circ} \mathrm{C}$ but the ratio of diplopterol to the sum of the six hopanols was on average at $0.1 \pm 0.0$ at 
TABLE 4 | Relative percentage of bulk fatty acids in Methylovulum psychrotolerans strains Sph1 ${ }^{\top}, \mathrm{OZ2}$, and Sph56 measured at 4,10 and $20^{\circ} \mathrm{C}$.

\begin{tabular}{|c|c|c|c|c|}
\hline Strain & & $20^{\circ} \mathrm{C}$ & $10^{\circ} \mathrm{C}$ & $4^{\circ} \mathrm{C}$ \\
\hline \multirow[t]{5}{*}{ Av. 3 strains } & Total $\mathrm{C}_{16}$ & $91 \pm 0.5$ & $86 \pm 0.8$ & $88 \pm 1.5$ \\
\hline & Total $\mathrm{C}_{15}$ & $0.5 \pm 0.0$ & $0.5 \pm 0.1$ & $0.5 \pm 0.1$ \\
\hline & Total $\mathrm{C}_{14}$ & $8.3 \pm 0.4$ & $14 \pm 0.7$ & $13 \pm 1.5$ \\
\hline & Total unsaturated & $79 \pm 2.0$ & $87 \pm 3.1$ & $89 \pm 0.9$ \\
\hline & Ratio $\beta \mathrm{OH}-\mathrm{C}_{16: 0} / \mathrm{C}_{16: 0}$ & $0.2 \pm 0.0$ & $0.9 \pm 0.2$ & $0.9 \pm 0.3$ \\
\hline \multirow[t]{14}{*}{$\operatorname{Sph}^{\top}$} & $\mathrm{C}_{14: 1 \omega 7}$ & $0.6 \pm 0.1$ & $4.5 \pm 0.0$ & $5.0 \pm 0.1$ \\
\hline & $\mathrm{C}_{14: 0}$ & $7.2 \pm 0.0$ & $9.1 \pm 0.1$ & $7.4 \pm 0.2$ \\
\hline & $\mathrm{C}_{15: 0}$ & $0.5 \pm 0.0$ & $0.5 \pm 0.0$ & $0.4 \pm 0.0$ \\
\hline & $\mathrm{C}_{16: 1 \omega 8 \mathrm{c}}$ & $31 \pm 3.3$ & $15 \pm 1.9$ & $30 \pm 0.2$ \\
\hline & $\mathrm{C}_{16: 1 \omega 7 \mathrm{c}}$ & $31 \pm 3.2$ & $51 \pm 3.0$ & $29 \pm 0.2$ \\
\hline & $\mathrm{C}_{16: 1 \omega 6 \mathrm{c}}$ & $4.3 \pm 0.1$ & $5.7 \pm 0.2$ & $8.5 \pm 0.4$ \\
\hline & $\mathrm{C}_{16: 1 \omega 5 \mathrm{tr}}$ & $12 \pm 0.2$ & $11 \pm 0.9$ & $16 \pm 0.3$ \\
\hline & $\mathrm{C}_{16: 0}$ & $12 \pm 0.1$ & $1.7 \pm 0.0$ & $1.4 \pm 0.0$ \\
\hline & $\beta \mathrm{OH}-\mathrm{C}_{16: 0}$ & $1.9 \pm 0.3$ & $1.7 \pm 0.2$ & $1.2 \pm 0.0$ \\
\hline & Total $\mathrm{C}_{16}$ & $92 \pm 0.1$ & $86 \pm 0.2$ & $87 \pm 0.1$ \\
\hline & Total $\mathrm{C}_{15}$ & $0.5 \pm 0.0$ & $0.5 \pm 0.0$ & $0.4 \pm 0.0$ \\
\hline & Total $\mathrm{C}_{14}$ & $8.0 \pm 0.0$ & $14 \pm 0.2$ & $12 \pm 0.1$ \\
\hline & Total unsaturated & $79 \pm 0.2$ & $87 \pm 0.0$ & $89 \pm 0.2$ \\
\hline & Ratio $\beta \mathrm{OH}-\mathrm{C}_{16: 0} / \mathrm{C}_{16: 0}$ & $0.2 \pm 0.0$ & $1.0 \pm 0.1$ & $0.9 \pm 0.0$ \\
\hline \multirow[t]{14}{*}{$\mathrm{OZ2}$} & $\mathrm{C}_{14: 1 \omega 7}$ & $0.7 \pm 0.0$ & $4.2 \pm 0.0$ & $4.5 \pm 0.3$ \\
\hline & $\mathrm{C}_{14: 0}$ & $8.0 \pm 0.0$ & $9.1 \pm 0.5$ & $6.5 \pm 0.2$ \\
\hline & $\mathrm{C}_{15: 0}$ & $0.6 \pm 0.0$ & $0.4 \pm 0.1$ & $0.5 \pm 0.0$ \\
\hline & $\mathrm{C}_{16: 1 \omega 8 \mathrm{c}}$ & $29 \pm 0.0$ & $16 \pm 1.2$ & $35 \pm 0.1$ \\
\hline & $\mathrm{C}_{16: 1 \omega 7 \mathrm{c}}$ & $27 \pm 0.5$ & $48 \pm 0.8$ & $28 \pm 0.5$ \\
\hline & $C_{16: 1 \omega 6 c}$ & $5.0 \pm 0.0$ & $7.0 \pm 0.8$ & $7.3 \pm 0.1$ \\
\hline & $\mathrm{C}_{16: 1 \omega 5 \mathrm{tr}}$ & $17 \pm 0.3$ & $12 \pm 0.5$ & $16 \pm 0.1$ \\
\hline & $\mathrm{C}_{16: 0}$ & $11 \pm 0.3$ & $2.0 \pm 0.1$ & $1.4 \pm 0.0$ \\
\hline & $\beta O H-C_{16: 0}$ & $1.8 \pm 0.1$ & $1.3 \pm 0.2$ & $0.8 \pm 0.0$ \\
\hline & Total $\mathrm{C}_{16}$ & $91 \pm 0.0$ & $86 \pm 0.6$ & $88 \pm 0.6$ \\
\hline & Total $\mathrm{C}_{15}$ & $0.6 \pm 0.0$ & $0.4 \pm 0.1$ & $0.5 \pm 0.0$ \\
\hline & Total $\mathrm{C}_{14}$ & $9.0 \pm 0.0$ & $13 \pm 0.5$ & $11 \pm 0.5$ \\
\hline & Total unsaturated & $79 \pm 0.2$ & $87 \pm 0.9$ & $91 \pm 0.3$ \\
\hline & Ratio $\beta \mathrm{OH}-\mathrm{C}_{16: 0} / \mathrm{C}_{16: 0}$ & $0.2 \pm 0.0$ & $0.6 \pm 0.0$ & $0.5 \pm 0.0$ \\
\hline \multirow[t]{14}{*}{ Sph56 } & $\mathrm{C}_{14: 1 \omega 7}$ & $0.8 \pm 0.0$ & $4.9 \pm 0.3$ & $5.6 \pm 0.2$ \\
\hline & $\mathrm{C}_{14: 0}$ & $7.7 \pm 0.2$ & $9.9 \pm 0.3$ & $8.5 \pm 0.3$ \\
\hline & $\mathrm{C}_{15: 0}$ & $0.6 \pm 0.1$ & $0.6 \pm 0.0$ & $0.6 \pm 0.0$ \\
\hline & $\mathrm{C}_{16: 1 \omega 8 \mathrm{c}}$ & $31 \pm 0.3$ & $24 \pm 1.8$ & $30 \pm 0.6$ \\
\hline & $\mathrm{C}_{16: 1 \omega 7 \mathrm{c}}$ & $22 \pm 0.0$ & $35 \pm 2.5$ & $30 \pm 0.3$ \\
\hline & $\mathrm{C}_{16: 1 \omega 6 \mathrm{c}}$ & $5.6 \pm 0.1$ & $7.4 \pm 0.1$ & $7.1 \pm 0.1$ \\
\hline & $\mathrm{C}_{16: 1 \omega 5 \mathrm{tr}}$ & $21 \pm 0.2$ & $15 \pm 0.3$ & $16 \pm 0.5$ \\
\hline & $\mathrm{C}_{16: 0}$ & $9.6 \pm 0.3$ & $1.7 \pm 0.1$ & $1.5 \pm 0.1$ \\
\hline & $\beta O H-\mathrm{C}_{16: 0}$ & $1.7 \pm 0.2$ & $1.8 \pm 0.2$ & $1.7 \pm 0.4$ \\
\hline & Total $\mathrm{C}_{16}$ & $91 \pm 0.2$ & $85 \pm 0.6$ & $85 \pm 0.5$ \\
\hline & Total $\mathrm{C}_{15}$ & $0.6 \pm 0.1$ & $0.6 \pm 0.0$ & $0.6 \pm 0.0$ \\
\hline & Total $\mathrm{C}_{14}$ & $8 \pm 0.1$ & $15 \pm 0.6$ & $14 \pm 0.4$ \\
\hline & Total unsaturated & $80 \pm 0.6$ & $86 \pm 0.0$ & $88 \pm 0.7$ \\
\hline & $\beta \mathrm{OH}-\mathrm{C}_{16: 0} / \mathrm{C}_{16: 0}$ & $0.2 \pm 0.0$ & $1.1 \pm 0.0$ & $1.2 \pm 0.2$ \\
\hline
\end{tabular}

both 10 and $4{ }^{\circ} \mathrm{C}$. During hopanoid biosynthesis, the cyclisation of squalene results in either the production of diploptene or diplopterol, but it is diploptene that is reported to be the pre-cursor in the biosynthesis of BHPs. The relative increase in diplopterol with decreasing temperature suggests an additional membrane adaption separate from that of the BHPs.

\section{Processes and Implications of Lipid Remodeling}

Overall, as the growth temperature decreased from 20 to $4^{\circ} \mathrm{C}$, the percent of unsaturated M. psychrotolerans bulk-FAs increased from 79 to $89 \%$ while the total percent of unsaturated IPL-bound-FAs increased from 69 to 81\% (Figure 5). Increased FA unsaturation in response to decreased temperature is a commonly observed response in order to maintain the liquid-crystalline character of bacterial membranes (Marr and Ingraham, 1962; Suutari and Laakso, 1994; Chattopadhyay, 2006; Guschina and Harwood, 2006; Barria et al., 2013; Siliakus et al., 2017). Certain bacteria have been shown to contain cold acclimation proteins (Caps) (Jones and Inouye, 1994; Berger et al., 1996), which include acyl lipid desaturases (Carty et al., 1999; Vorachek-Warren et al., 2002; Albanesi et al., 2004). These enzymes belong to the FA desaturase family (FAD) and are known to be regulated in all organisms by feedback mechanisms in which sensor proteins control the transcription of genes that modify pre-formed lipids (Aguilar and de Mendoza, 2006).

Hopanoids are involved in increasing membrane stability in certain bacteria (Welander et al., 2009; Schmerk et al., 2011) and their structure can undergo post-synthesis modifications such as methylation and side chain modifications (Welander and Summons, 2012). The most notable hopanoid temperature adaption of $M$. psychrotolerans was an increase in unsaturated hopanoids with decreasing temperature, from 27 to $49 \%$ (Figure 5). The presence of hopanoids is a common feature to all investigated obligate methanotrophs (Cvejic et al., 2000b), however very few studies have described the presence of unsaturated hopanoids. Furthermore, increased hopanoid unsaturation upon cold exposure has not been described previously and hence the enzymes responsible for the desaturation of the hopanoid core have not previously been established.

In order to investigate the mechanisms of both FA and hopanoid cold-adaption in M. psychrotolerans, we examined its genome for $M$. psychrotolerans for the presence of genes that potentially code for fatty acid desaturases. We identified the AADEFJLK_03363 gene that codes for the POZ50891 protein, which is annotated as a potential FA desaturase enzyme. Topology analysis of this protein predicted that it forms four trans-membrane helices, which suggests it is an integral membrane protein (Aguilar et al., 1998). In addition, enzymes from the FAD usually contain highly conserved histidine-rich motifs, which we also identified in POZ50891 FA desaturase $\left(\mathrm{H}_{98} \mathrm{XXXH}_{102}, \mathrm{H}_{134} \mathrm{XXH}_{137} \mathrm{H}_{138}, \mathrm{H}_{261} \mathrm{H}_{262} \mathrm{XH}_{264}\right.$, $\mathrm{H}_{307} \mathrm{XXH}_{310} \mathrm{H}_{311}$ ). In order to investigate the enzymatic mechanisms responsible for hopanoid unsaturation, we searched for genes that potentially code for proteins involved in this reaction. We identified a gene AADEFJLK_00554 coding for a potential sterol desaturase POZ53527 protein, belonging to the FA hydroxylase (FAH) superfamily of proteins. Within this group, a wide set of enzymatic activities related to 


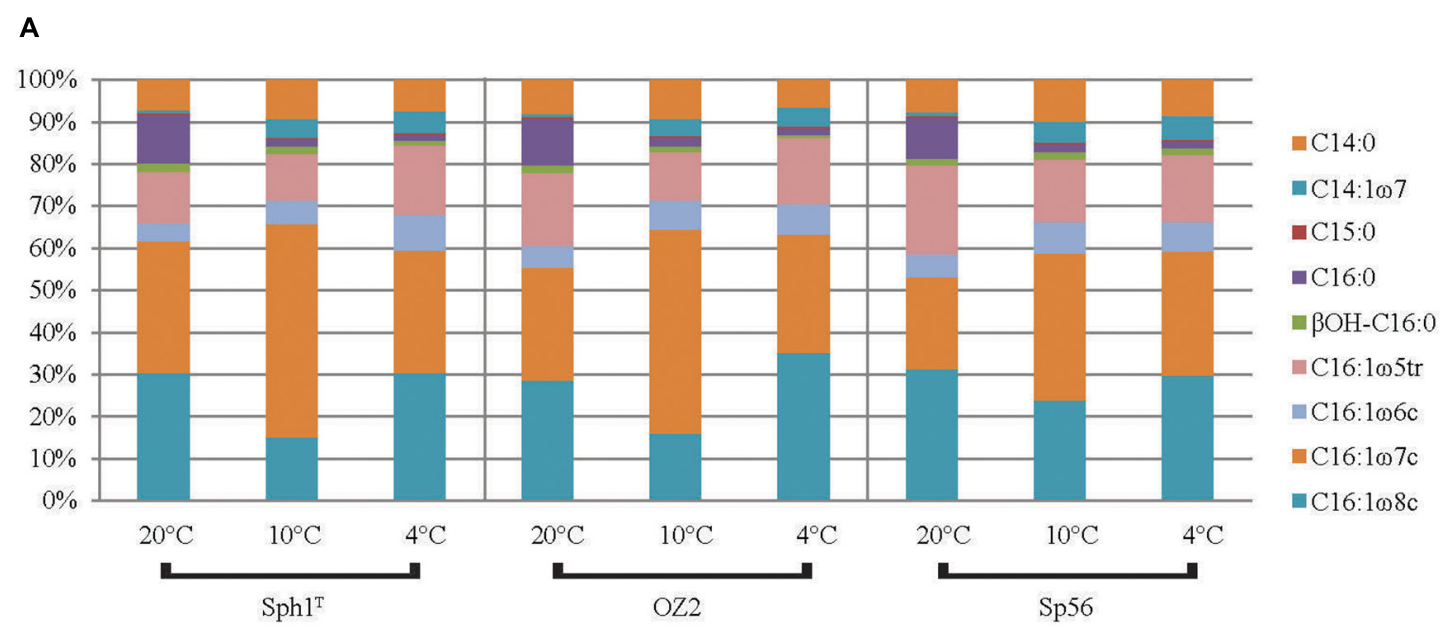

B

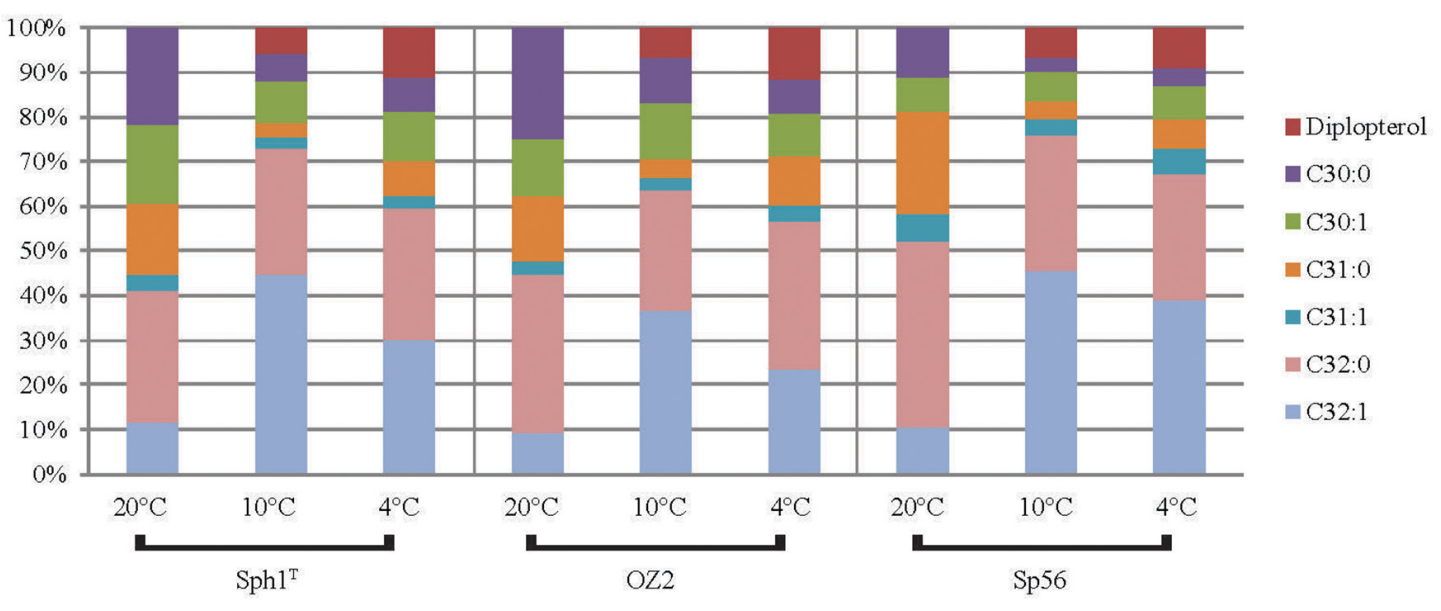

FIGURE 4 | The distribution of (A) FAs and (B) hopanols formed by Rohmer degradation (including diplopterol) for the three Methylovulum psychrotolerans strains $\mathrm{Sph}^{\top}{ }^{\top}, \mathrm{OZ2}$, and Sph56 (average of duplicate cultures) at the three growth temperatures.

hydroxylation, desaturation and oxidation have been described (Arthington et al., 1991; Bard et al., 1996; Mitchell and Martin, 1997; Ternes et al., 2002; Vences-Guzmán et al., 2011) (cf. Supplementary Table S3). Sterol and sterol-derived molecules are not produced by $M$. psychrotolerans, but hopanoids are considered structural analogs, therefore we postulate that the POZ53527 protein present in $M$. psychrotolerans could be involved in hopanoid desaturation, as has been postulated previously for similar sterol desaturases (Tushar et al., 2014). Topology analysis of the POZ53527 protein revealed five transmembrane helices, suggesting that this protein is also an integral membrane protein, as well as the histidine rich motifs typically found in FAH family of proteins (Supplementary Figure S3).

Both the FA desaturase and the sterol desaturase identified here are integral membrane histidine motif-containing enzymes (IMHME) (Cid et al., 2017). Their sequence analyses revealed that they belong to the FAD and the FAH superfamilies, respectively. According to this classification, M. psychrotolerans contains one protein of each group, and both proteins can be actively involved in lipid modification under low temperature

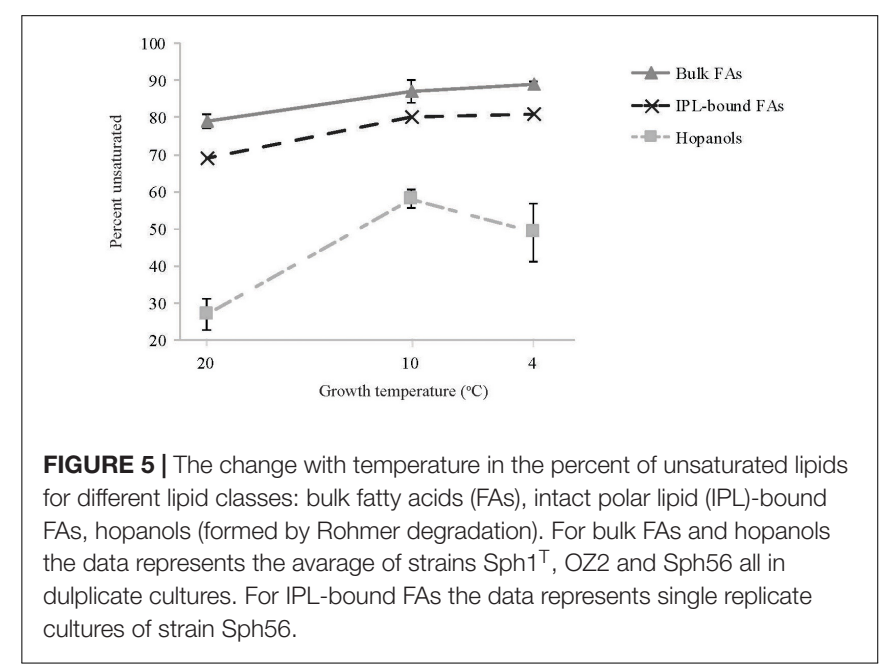

conditions. Among the FAD family of proteins, the bacterial FA desaturase $(\Delta 5$-Des) of $B$. subtilis has been characterized 
and it is known to be transcriptionally regulated in response to decreased temperature (Aguilar et al., 1998). Proteins that belong to the FAH family of proteins, are very diverse in their activities and substrate specificities (Cid et al., 2017) (Summarized in Supplementary Table S3). The potential M. psychrotolerans hopanoid desaturase protein POZ53527 belongs to this classification and will represent a novel enzymatic activity related to the substrate specificity to hopanoids. Thus, we propose that the unsaturation of hopanoids represents a novel membrane remodeling feature in order to maintain the membrane homeostasis upon cold adaptation. If this hypothesis is correct, these results may be useful for studies of the natural environment. Indeed, it may possible to make inferences from the proportion of $\Delta^{11}$ unsaturated hopanoids about growth temperature or the ecological niche of BHP producers, in particular in low-temperature environments. However, to date the reports of $\Delta^{11}$ unsaturated hopanoids in the natural environment are limited (e.g., Cooke et al., 2008; Handley et al., 2010; Spencer-Jones et al., 2015; Rush et al., 2016).

\section{CONCLUSION}

Three strains of Methylovulum psychrotolerans were grown at three different growth temperatures, $20^{\circ} \mathrm{C}, 10^{\circ} \mathrm{C}$ and $4^{\circ} \mathrm{C}$ and were capable of oxidizing methane down to $4^{\circ} \mathrm{C}$. The three M. psychrotolerans strains adapted to decreasing growth temperature by increasing unsaturation in both FAs (bulk and IPL-bound) and hopanoids. The bulk FA ratio of $\beta \mathrm{OH}-\mathrm{C}_{16: 0}$ to $\mathrm{C}_{16: 0}$ increased as growth temperature decreased. The hopanol composition of $M$. psychrotolerans contains $\mathrm{C}_{30: 0}, \mathrm{C}_{31: 0}$ and $\mathrm{C}_{32: 0}$ along with their unsaturated forms. The most notable hopanoid adaption $M$. psychrotolerans exhibited to lower growth temperatures was an increase in $\mathrm{C}_{32: 1}$ hopanols (formed from unsaturated tetrafunctionalised BHPs). The total sum of $\mathrm{C}_{32}$ hopanols increased as temperature decreased. Similar results have been reported in other studies. Diplopterol was not detected in the cultures grown at $20^{\circ} \mathrm{C}$ but was present at 10 and $4^{\circ} \mathrm{C}$.

Our results demonstrate that not only FAs, but also hopanoids can be remodeled to maintain bacterial membrane homeostasis

\section{REFERENCES}

Aguilar, P. S., Cronan, J. E., and de Mendoza, D. (1998). A Bacillus subtilis gene induced by cold shock encodes a membrane phospholipid desaturase. J. Bacteriol. 180, 2194-2200.

Aguilar, P. S., and de Mendoza, D. (2006). Control of fatty acid desaturation: a mechanism conserved from bacteria to humans. Mol. Microbiol. 62, 1507-1514. doi: 10.1111/j.1365-2958.2006.05484.x

Albanesi, D., Mansilla, M. C., and de Mendoza, D. (2004). The membrane fluidity sensor DesK of Bacillus subtilis controls the signal decay of its cognate response regulator. J. Bacteriol. 186, 2655-2663.

Arthington, B. A., Bennett, L. G., Skatrud, P. L., Guynn, C. J., Barbuch, R. J., Ulbright, C. E., et al. (1991). Cloning, disruption and sequence of the gene encoding yeast C-5 sterol desaturase. Gene 102, 39-44.

Auman, A. J., Breezee, J. L., Gosink, J. J., Kämpfer, P., and Staley, J. T. (2006). Psychromonas ingrahamii sp. nov., a novel gas vacuolate, psychrophilic bacterium isolated from Arctic polar sea ice. Int. J. Syst. Evol. Microbiol. 56, 1001-1007. doi: 10.1099/ijs.0.64068-0 upon cold adaptation. We identified genes that potentially code for FA lipid desaturases and for hopanoid unsaturation in the genome of $M$. psychrotolerans. Further work would be needed to produce the biochemical evidence of the enzymatic activity of the proposed membrane-adaption genes in M. psychrotolerans.

\section{AUTHOR CONTRIBUTIONS}

NB carried out data analysis and wrote the manuscript. WR carried out extractions and lipid analysis. DS-C carried out genomic analyses. IO and SB cultured bacteria and measured methane oxidation rates. SD and JSD designed and supervised the study.

\section{FUNDING}

This project received funding from the European Research Council (ERC) under the European Union's Horizon 2020 research and innovation program (Grant Agreement No. 694569). IO, SB, and SD were supported by the Ministry of Science and High Education of Russia.

\section{ACKNOWLEDGMENTS}

We thank E. Hopmans for help and expertise in sample analysis and data interpretation. We also thank D. Rush, N. Smit, L. Villanueva and S. Schouten for invaluable discussions during preparation of this manuscript. We thank the reviewers for constructive and helpful suggestions that greatly improved this paper.

\section{SUPPLEMENTARY MATERIAL}

The Supplementary Material for this article can be found online at: https://www.frontiersin.org/articles/10.3389/fmicb. 2019.00589/full\#supplementary-material

Bard, M., Bruner, D. A., Pierson, C. A., Lees, N. D., Biermann, B., Frye, L., et al. (1996). Cloning and characterization of ERG25, the Saccharomyces cerevisiae gene encoding C-4 sterol methyl oxidase. Proc. Natl. Acad. Sci. U.S.A. 93, 186-190.

Barria, C., Malecki, M., and Arraiano, C. M. (2013). Bacterial adaptation to cold. Microbiology 159, 2437-2443. doi: 10.1099/mic.0.052209-0

Berger, F., Morellet, N., Menu, F., and Potier, P. (1996). Cold shock and cold acclimation proteins in the psychrotrophic bacterium Arthrobacter globiformis SI55. J. Bacteriol. 178, 2999-3007. doi: 10.1128/jb.178.11.29993007.1996

Bligh, E., and Dyer, W. (1959). A rapid method of total lipid extraction and purification. Can. J. Biochem. Phys. 37, 911-917.

Bodelier, P. L. E., Gillisen, M.-J. B., Hordijk, K., Damsté, J. S. S., Rijpstra, W. I. C., Geenevasen, J. A. J., et al. (2009). A reanalysis of phospholipid fatty acids as ecological biomarkers for methanotrophic bacteria. ISME J. 3, 606-617. doi: 10.1038 /ismej.2009.6

Bowman, J. (2006). "The methanotrophs - The families methylococcaceae and methylocystaceae," in The Prokaryotes, eds M. Dworkin, S. Falkow, E. 
Rosenberg, K. H. Schleifer, and E. Stackebrandt (New York, NY: Springer), 266-289. doi: 10.1007/0-387-30745-1_15

Bowman, J. P., Skerratt, J. H., Nichols, P. D., and Sly, L. I. (1991). Phospholipid fatty acid and lipopolysaccharide fatty acid signature lipids in methane-utilizing bacteria. FEMS Microbiol. Lett. 85, 15-21.

Brandsma, J., Hopmans, E. C., Brussaard, C. P. D., Witte, H. J., Schouten, S., and Sinninghe Damsté, J. S. (2012). Spatial distribution of intact polar lipids in North Sea surface waters: Relationship with environmental conditions and microbial community composition. Limnol. Oceanogr. 57, 959-973. doi: 10. 4319/lo.2012.57.4.0959

Breezee, J., Cady, N., and Staley, J. T. (2004). Subfreezing growth of the sea ice bacterium "Psychromonas ingrahamii." Microb. Ecol. 47, 300-304. doi: 10.1007/ s00248-003-1040-9

Brügger, B., Erben, G., Sandhoff, R., Wieland, F. T., and Lehmann, W. D. (1997). Quantitative analysis of biological membrane lipids at the low picomole level by nano-electrospray ionization tandem mass spectrometry. Proc. Natl. Acad. Sci. U.S.A. 94, 2339-2344.

Carty, S. M., Sreekumar, K. R., and Raetz, C. R. H. (1999). Effect of cold shock on lipid A biosynthesis in Escherichia coli. Induction at $12{ }^{\circ} \mathrm{C}$ of an acyltransferase specific for palmitoleoyl-acyl carrier protEIN. J. Biol. Chem. 274, 9677-9685. doi: $10.1074 /$ jbc.274.14.9677

Chattopadhyay, M. K. (2006). Mechanism of bacterial adaptation to low temperature. J. Biosci. 31, 157-165.

Chattopadhyay, M. K., Jagannadham, M. V., Vairamani, M., and Shivaji, S. (1997). Carotenoid pigments of an antarctic psychrotrophic bacterium Micrococcus roseus: temperature dependent biosynthesis, structure, and interaction with synthetic membranes. Biochem. Biophys. Res. Commun. 239, 85-90. doi: 10. 1006/bbrc. 1997.7433

Chintalapati, S., Kiran, M. D., and Shivaji, S. (2004). Role of membrane lipid fatty acids in cold adaptation. Cell. Mol. Biol. 50, 631-642.

Chojnacki, S., Cowley, A., Lee, J., Foix, A., and Lopez, R. (2017). Programmatic access to bioinformatics tools from EMBL-EBI update: 2017. Nucleic Acids Res. 45, W550-W553. doi: 10.1093/nar/gkx273

Cid, N. G., Sanchez Granel, M. L., Montes, M. G., Elguero, M. E., Nudel, C. B., and Nusblat, A. D. (2017). Phylogenomic analysis of integral diiron membrane histidine motif-containing enzymes in ciliates provides insights into their function and evolutionary relationships. Mol. Phylogenet. Evol. 114, 1-13. doi: 10.1016/j.ympev.2017.05.023

Cooke, M. P., Talbot, H. M., and Farrimond, P. (2008). Bacterial populations recorded in bacteriohopanepolyol distributions in soils from Northern England. Org. Geochem. 39, 1347-1358. doi: 10.1016/j.orggeochem.2008.05.003

Cvejic, J. H., Bodrossy, L., Kovács, K. L., and Rohmer, M. (2000a). Bacterial triterpenoids of the hopane series from the methanotrophic bacteria Methylocaldum spp.: phylogenetic implications and first evidence for an unsaturated aminobacteriohopanepolyol. FEMS Microbiol. Lett. 182, 361-365.

Cvejic, J. H., Putra, S. R., El-Beltagy, A., Hattori, R., Hattori, T., and Rohmer, M. (2000b). Bacterial triterpenoids of the hopane series as biomarkers for the chemotaxonomy of Burkholderia, Pseudomonas and Ralstonia spp. FEMS Microbiol. Lett. 183, 295-299.

Dedysh, S. N., Belova, S. E., Bodelier, P. L. E., Smirnova, K. V., Khmelenina, V. N., Chidthaisong, A., et al. (2007). Methylocystis heyeri sp. nov., a novel type II methanotrophic bacterium possessing "signature" fatty acids of type I methanotrophs. Int. J. Syst. Evol. Microbiol. 57, 472-479. doi: 10.1099/ijs.0. 64623-0

Fang, J., Barcelona, M. J., and Semrau, J. D. (2000). Characterization of methanotrophic bacteria on the basis of intact phospholipid profiles. FEMS Microbiol. Lett. 189, 67-72. doi: 10.1111/j.1574-6968.2000.tb09207.x

Feller, G., and Gerday, C. (2003). Psychrophilic enzymes: hot topics in cold adaptation. Nat. Rev. Microbiol. 1, 200-208. doi: 10.1038/nrmicro773

Guan, Z., Tian, B., Perfumo, A., and Goldfine, H. (2013). The polar lipids of Clostridium psychrophilum, an anaerobic psychrophile. Biochim. Biophys. Acta 1831, 1108-1112. doi: 10.1016/j.bbalip.2013.02.004

Guschina, I. A., and Harwood, J. L. (2006). Mechanisms of temperature adaptation in poikilotherms. FEBS Lett. 580, 5477-5483. doi: 10.1016/j.febslet.2006. 06.066

Handley, L., Talbot, H. M., Cooke, M. P., Anderson, K. E., and Wagner, T. (2010). Bacteriohopanepolyols as tracers for continental and marine organic matter supply and phases of enhanced nitrogen cycling on the late Quaternary Congo deep sea fan. Org. Geochem. 41, 910-914. doi: 10.1016/j.orggeochem.2010. 04.016

Hanson, R. S., and Hanson, T. E. (1996). Methanotrophic bacteria. Microbiol. Rev. $60,439-471$.

Hermans, M. A., Neuss, B., and Sahm, H. (1991). Content and composition of hopanoids in Zymomonas mobilis under various growth conditions. J. Bacteriol. 173, 5592-5595.

Herrmann, D., Bisseret, P., Connan, J., and Rohmer, M. (1996). A non-extractable triterpenoid of the hopane series in Acetobacter xylinum. FEMS Microbiol. Lett. 135, 323-326. doi: 10.1111/j.1574-6968.1996.tb08008.x

Iguchi, H., Yurimoto, H., and Sakai, Y. (2011). Methylovulum miyakonense gen. nov., sp. nov., a type I methanotroph isolated from forest soil. Int. J. Syst. Evol. Microbiol. 61, 810-815. doi: 10.1099/ijs.0.019604-0

Jagannadham, M. V., Chattopadhyay, M. K., Subbalakshmi, C., Vairamani, M., Narayanan, K., Rao, C. M., et al. (2000). Carotenoids of an Antarctic psychrotolerant bacterium, Sphingobacterium antarcticus, and a mesophilic bacterium, Sphingobacterium multivorum. Arch. Microbiol. 173, 418-424.

Jahnke, L. L., Summons, R. E., Hope, J. M., and Des Marais, D. J. (1999). Carbon isotopic fractionation in lipids from methanotrophic bacteria II: the effects of physiology and environmental parameters on the biosynthesis and isotopic signatures of biomarkers. Geochim. Cosmochim. Acta 63, 79-93. doi: 10.1016/ S0016-7037(98)00270-1

Jones, P. G., and Inouye, M. (1994). The cold-shock response-a hot topic. Mol. Microbiol. 11, 811-818.

Joyeux, C., Fouchard, S., Llopiz, P., and Neunlist, S. (2004). Influence of the temperature and the growth phase on the hopanoids and fatty acids content of Frateuria aurantia (DSMZ 6220). FEMS Microbiol. Ecol. 47, 371-379. doi: $10.1016 /$ S0168-6496(03)00302-7

Katoh, K., and Standley, D. M. (2013). MAFFT multiple sequence alignment software version 7: improvements in performance and usability. Mol. Biol. Evol. 30, 772-780. doi: 10.1093/molbev/mst010

Keinänen, M. M., Korhonen, L. K., Martikainen, P. J., Vartiainen, T., Miettinen, I. T., Lehtola, M. J., et al. (2003). Gas chromatographic-mass spectrometric detection of 2- and 3-hydroxy fatty acids as methyl esters from soil, sediment and biofilm. J. Chromatogr. B Analyt. Technol. Biomed. Life Sci. 783, 443-451.

Klok, J., Baas, M., Cox, H. C., de Leeuw, J. W., Rijpstra, W. I. C., and Schenck, P. A. (1988). The mode of occurrence of lipids in a Namibian Shelf diatomaceous ooze with emphasis on the $\beta$-hydroxy fatty acids. Org. Geochem. 12, 75-80. doi: 10.1016/0146-6380(88)90116-7

Knief, C., and Dunfield, P. F. (2005). Response and adaptation of different methanotrophic bacteria to low methane mixing ratios. Environ. Microbiol. 7, 1307-1317. doi: 10.1111/j.1462-2920.2005.00814.x

Lee, A. K. Y., Chan, C. K., Fang, M., and Lau, A. P. S. (2004). The 3-hydroxy fatty acids as biomarkers for quantification and characterization of endotoxins and Gram-negative bacteria in atmospheric aerosols in Hong Kong. Atmos. Environ. 38, 6307-6317. doi: 10.1016/j.atmosenv.2004.08.013

Marr, A. G., and Ingraham, J. L. (1962). Effect of temperature on the composition of fatty acids in Escherichia coli. J. Bacteriol. 84, 1260-1267.

Mitchell, A. G., and Martin, C. E. (1997). Fah1p, a Saccharomyces cerevisiae cytochrome $b_{5}$ fusion protein, and Its Arabidopsis thaliana homolog that lacks the cytochrome $b_{5}$ domain both function in the $\alpha$-hydroxylation of sphingolipid-associated very long chain fatty acids. J. Biol. Chem. 272, 28281-28288. doi: 10.1074/jbc.272.45.28281

Nichols, P. D., Glen, A. S., Antworth, C. P., Hanson, R. S., and White, D. C. (1985). Phospholipid and lipopolysaccharide normal and hydroxy fatty acids as potential signatures for methane-oxidizing bacteria. FEMS Microbiol. Lett. 31, 327-335. doi: 10.1016/0378-1097(85) 90028-X

Osborne, K. A., Gray, N. D., Sherry, A., Leary, P., Mejeha, O., Bischoff, J., et al. (2017). Methanotroph-derived bacteriohopanepolyol signatures as a function of temperature related growth, survival, cell death and preservation in the geological record. Environ. Microbiol. Rep. 9, 492-500. doi: 10.1111/1758-2229. 12570

Oshkin, I. Y., Belova, S. E., Danilova, O. V., Miroshnikov, K. K., Rijpstra, W. I. C., Sinninghe Damsté, J. S., et al. (2016). Methylovulum psychrotolerans sp. nov., a cold-adapted methanotroph from low-temperature terrestrial environments, and emended description of the genus Methylovulum. Int. J. Syst. Evol. Microbiol. 66, 2417-2423. doi: 10.1099/ijsem.0.001046 
Oshkin, I. Y., Miroshnikov, K. K., Belova, S. E., Korzhenkov, A. A., Toshchakov, S. V., and Dedysh, S. N. (2018). Draft genome sequence of Methylovulum psychrotolerans Sph1T, an obligate methanotroph from low-temperature environments. Genome Announc. 6:e01488-17. doi: 10.1128/genomeA. 01488-17

Poralla, K., Härtner, T., and Kannenberg, E. (1984). Effect of temperature and pH on the hopanoid content of Bacillus acidocaldarius. FEMS Microbiol. Lett. 23, 253-256. doi: 10.1111/j.1574-6968.1984.tb01073.x

Rohmer, M., Bouvier-Nave, P., and Ourisson, G. (1984). Distribution of hopanoid triterpenes in prokaryotes. Microbiology 130, 1137-1150. doi: 10 . 1099/00221287-130-5-1137

Rohmer, M., and Ourisson, G. (1976). Dérivés du bactériohopane: variations structurales et répartition. Tetrahedron Lett. 17, 3637-3640. doi: 10.1016/ S0040-4039(00)92981-2

Rush, D., Osborne, K. A., Birgel, D., Kappler, A., Hirayama, H., Peckmann, J., et al. (2016). The bacteriohopanepolyol inventory of novel aerobic methane oxidising bacteria reveals new biomarker signatures of aerobic methanotrophy in marine systems. PLoS One 11:e0165635. doi: 10.1371/journal.pone.0165635

Schmerk, C. L., Bernards, M. A., and Valvano, M. A. (2011). Hopanoid production is required for low-pH tolerance, antimicrobial resistance, and motility in Burkholderia cenocepacia. J. Bacteriol. 193, 6712-6723. doi: 10.1128/JB. 05979-11

Shivaji, S., and Prakash, J. S. S. (2010). How do bacteria sense and respond to low temperature? Arch. Microbiol. 192, 85-95. doi: 10.1007/s00203-009-0539-y

Siliakus, M. F., van der Oost, J., and Kengen, S. W. M. (2017). Adaptations of archaeal and bacterial membranes to variations in temperature, $\mathrm{pH}$ and pressure. Extremophiles 21, 651-670. doi: 10.1007/s00792-017-0939-x

Simonin, P., Tindall, B., and Rohmer, M. (1994). Structure elucidation and biosynthesis of 31-methylhopanoids from Acetobacter europaeus. Studies on a new series of bacterial triterpenoids. Eur. J. Biochem. 225, 765-771.

Spencer-Jones, C. L., Wagner, T., Dinga, B. J., Schefuß, E., Mann, P. J., Poulsen, J. R., et al. (2015). Bacteriohopanepolyols in tropical soils and sediments from the Congo River catchment area. Org. Geochem. 8, 1-13. doi: 10.1016/j. orggeochem.2015.09.003

Sundh, I., Bastviken, D., and Tranvik, L. J. (2005). Abundance, activity, and community structure of pelagic methane-oxidizing bacteria in temperate lakes. Appl. Environ. Microbiol. 71, 6746-6752. doi: 10.1128/AEM.71.11.6746-6752. 2005

Suutari, M., and Laakso, S. (1994). Microbial fatty acids and thermal adaptation. Crit. Rev. Microbiol. 20, 285-328. doi: 10.3109/10408419409113560

Talbot, H. M., Rohmer, M., and Farrimond, P. (2007a). Rapid structural elucidation of composite bacterial hopanoids by atmospheric pressure chemical ionisation liquid chromatography/ion trap mass spectrometry. Rapid Commun. Mass Spectrom. 21, 880-892. doi: 10.1002/rcm.2911

Talbot, H. M., Rohmer, M., and Farrimond, P. (2007b). Structural characterisation of unsaturated bacterial hopanoids by atmospheric pressure chemical ionisation liquid chromatography/ion trap mass spectrometry. Rapid Commun. Mass Spectrom. 21, 1613-1622. doi: 10.1002/rcm.2997

Ternes, P., Franke, S., Zähringer, U., Sperling, P., and Heinz, E. (2002). Identification and characterization of a sphingolipid $\Delta 4$-desaturase family. J. Biol. Chem. 277, 25512-25518. doi: 10.1074/jbc.M202947200

Trotsenko, Y. A., and Murrell, J. C. (2008). Metabolic aspects of aerobic obligate methanotrophy. Adv. Appl. Microbiol. 63, 183-229. doi: 10.1016/ S0065-2164(07)00005-6

Tushar, L., Sasikala, C., and Ramana, C. V. (2014). Draft genome sequence of Rhodomicrobium udaipurense $\mathrm{JA} 643^{\mathrm{T}}$ with special reference to hopanoid biosynthesis. DNA Res. 21, 639-647. doi: 10.1093/dnares/dsu026

van Winden, J. F. (2011). Methane Cycling in Peat Bogs: Environmental Relevance of Methanotrophs Revealed by Microbial Lipid Chemistry. Ph.D. thesis, Utrecht University, Utrecht. van Winden, J. F., Reichart, G.-J., McNamara, N. P., Benthien, A., and Damsté, J. S. S. (2012a). Temperature-induced increase in methane release from peat bogs: a mesocosm experiment. PLoS One 7:e39614. doi: 10.1371/journal.pone. 0039614

van Winden, J. F., Talbot, H. M., Kip, N., Reichart, G.-J., Pol, A., McNamara, N. P., et al. (2012b). Bacteriohopanepolyol signatures as markers for methanotrophic bacteria in peat moss. Geochim. Cosmochim. Acta 77, 52-61. doi: 10.1016/j.gca. 2011.10.026

Vences-Guzmán, M. Á, Guan, Z., Ormeño-Orrillo, E., González-Silva, N., López-Lara, I. M., Martínez-Romero, E., et al. (2011). Hydroxylated ornithine lipids increase stress tolerance in Rhizobium tropici CIAT899. Mol. Microbiol. 79, 1496-1514. doi: 10.1111/j.1365-2958.2011. 07535.x

Vorachek-Warren, M. K., Carty, S. M., Lin, S., Cotter, R. J., and Raetz, C. R. H. (2002). An Escherichia coli mutant lacking the cold shock-induced palmitoleoyltransferase of lipid A biosynthesis: absence of unsaturated acyl chains and antibiotic hypersensitivity at 12 degrees C. J. Biol. Chem. 277, 14186-14193. doi: 10.1074/jbc.M200408200

Wakeham, S. G., Pease, T. K., and Benner, R. (2003). Hydroxy fatty acids in marine dissolved organic matter as indicators of bacterial membrane material. Org. Geochem. 34, 857-868. doi: 10.1016/S0146-6380(02)00189-4

Wan, X., Peng, Y.-F., Zhou, X.-R., Gong, Y.-M., Huang, F.-H., and Moncalián, G. (2016). Effect of cerulenin on fatty acid composition and gene expression pattern of DHA-producing strain Colwellia psychrerythraea strain $34 \mathrm{H}$. Microb. Cell Fact. 15:30. doi: 10.1186/s12934-016-0431-9

Wang, C., Bendle, J., Yang, Y., Yang, H., Sun, H., Huang, J., et al. (2016). Impacts of $\mathrm{pH}$ and temperature on soil bacterial 3-hydroxy fatty acids: development of novel terrestrial proxies. Org. Geochem. 94, 21-31. doi: 10.1016/j.orggeochem. 2016.01.010

Waterhouse, A. M., Procter, J. B., Martin, D. M. A., Clamp, M., and Barton, G. J. (2009). Jalview Version 2-a multiple sequence alignment editor and analysis workbench. Bioinformatics 25, 1189-1191. doi: 10.1093/bioinformatics/ btp033

Welander, P. V., Hunter, R. C., Zhang, L., Sessions, A. L., Summons, R. E., and Newman, D. K. (2009). Hopanoids play a role in membrane integrity and $\mathrm{pH}$ homeostasis in Rhodopseudomonas palustris TIE-1. J. Bacteriol. 191, 6145-6156. doi: 10.1128/JB.00460-09

Welander, P. V., and Summons, R. E. (2012). Discovery, taxonomic distribution, and phenotypic characterization of a gene required for 3-methylhopanoid production. Proc. Natl. Acad. Sci. U.S.A. 109, 12905-12910. doi: 10.1073/pnas. 1208255109

Wollenweber, H.-W., and Rietschel, E. T. (1990). Analysis of lipopolysaccharide (lipid A) fatty acids. J. Microbiol. Methods 11, 195-211. doi: 10.1016/01677012(90)90056-C

Wörmer, L., Lipp, J. S., Schröder, J. M., and Hinrichs, K.-U. (2013). Application of two new LC-ESI-MS methods for improved detection of intact polar lipids (IPLs) in environmental samples. Org. Geochem. 59, 10-21. doi: 10.1016/j. orggeochem.2013.03.004

Conflict of Interest Statement: The authors declare that the research was conducted in the absence of any commercial or financial relationships that could be construed as a potential conflict of interest.

Copyright (C) 2019 Bale, Rijpstra, Sahonero-Canavesi, Oshkin, Belova, Dedysh and Sinninghe Damsté. This is an open-access article distributed under the terms of the Creative Commons Attribution License (CC BY). The use, distribution or reproduction in other forums is permitted, provided the original author(s) and the copyright owner(s) are credited and that the original publication in this journal is cited, in accordance with accepted academic practice. No use, distribution or reproduction is permitted which does not comply with these terms. 